\title{
The Use of Violence in Illegal Markets: Evidence from Mahogany Trade in the Brazilian Amazon*
}

\author{
Ariaster B. Chimeli ${ }^{\dagger}$ \\ and \\ Rodrigo R. Soares ${ }^{\ddagger}$
}

August 2010

\begin{abstract}
Agents operating in illegal markets cannot resort to the justice system to guarantee property rights or to seek protection from competitors' improper behaviors. In these contexts, violence is used to enforce previous agreements and to fight for market share. This relationship plays a major role in the debate on the pernicious effects of the illegality of drug trade. This paper explores a singular episode of transition of a market from legal to illegal to provide a first piece of evidence on the causal effect of illegality on violence. Brazil has historically been the main world producer of mahogany (a tropical wood). Starting in the 1990s, policies restricting extraction and trade of mahogany, culminating with prohibition, were implemented. First, we present evidence that large scale mahogany trade persisted after prohibition, through misclassification of mahogany exports as "other tropical timber species." Second, we document relative increases in violence after prohibition in: (i) states with higher share of total mahogany exports before prohibition; (ii) states with higher exports of "other tropical timber species" after prohibition; and (iii) municipalities within the area of natural occurrence of mahogany. We believe this is the first documented experience of increase in violence following the transition of a market from legal to illegal.
\end{abstract}

Keywords: illegal markets, violence, homicide, mahogany, Brazil

JEL codes: K42, 013, 017, Q58

\footnotetext{
* Excellent research assistance was provided by Bruno Vieira. This paper benefited from comments from seminar participants at IPEA-Rio. Contact information: chimeli at ohio.edu and soares at econ.puc-rio.br.

${ }^{+}$Ohio University

‡ Pontifical Catholic University of Rio de Janeiro and IZA
} 


\section{Introduction}

Agents operating in illegal markets cannot resort to the justice system to uphold contracts, to guarantee property rights, or to seek protection from competitors' improper behaviors. Instead, in these contexts, violence is used to enforce previous agreements and to fight for market share (for a case study, see Mieczkowski, 1990). This relationship plays a major role in the current debate on the pernicious effects of the illegality of drug trade and the War on Drugs (see, for example, Nadelmann, 1989, Miron and Zwiebel, 1995, and Keefer and Loayza, 2010). Anecdotal evidence from the American alcohol prohibition, the Opium Wars in China, and other historical experiences seems to support this view (see discussion and references in Fagan and Chin, 1990). Still, there is no uncontroversial and statistically robust evidence on the causal effect of illegality of trade on the incidence of violence. Randomized experimental evidence in this setting seems virtually impossible, while institutional changes leading to transitions of markets from legal to illegal - which could be used as natural experiments - are extremely rare.

This paper explores a singular episode of transition of a market from legal to illegal to provide a first piece of causal evidence on the increase in violence following the complete shutdown of a legal market. Brazil has historically been the main world producer of big leaf mahogany, an extremely valuable tropical wood. ${ }^{1}$ From the end of the 1990 s to the early 2000 s, the Brazilian government implemented a series of policies progressively restricting the extraction and trade of mahogany, culminating with prohibition in late 2001 . We analyze yearly data at both state and municipality levels, and use time-series and difference-in-difference strategies, to show that mahogany extraction persisted and was associated with increased violence after prohibition. Our identification trusts on the timing of implementation of restrictions to the mahogany trade and on three pieces of information on the relevance of mahogany for a given region. We have data on the natural occurrence of mahogany in the Brazilian territory, on state level mahogany exports before prohibition, and on exports of "other tropical timber species" after prohibition. Combinations of these variables can be used to

\footnotetext{
${ }^{1}$ Grogan et al (2002) claim that mahogany is one of the most valuable woods in the world, with the price per cubic meter for a high quality variety around US\$1,200 in 2001. The area of natural occurrence of big leaf mahogany is restricted to Central America and to the South American region of the Amazon. The total Brazilian production of mahogany between 1971 and 2001 is estimated to have been of the order of US\$ 4 billion, with 75\% corresponding to exports to the US and Europe (Grogan et al, 2002).
} 
explore double differences on the timing of change to illegality and the relevance of mahogany (natural availability or economic importance) for a given region, and also triple differences on timing of change, availability, and economic importance. Though in an entirely different context, our empirical strategy is similar to that used by Jayachandran and Lleras-Muney (2009) and Jayachandran et al (2010), when analyzing the impacts of innovations in health technologies.

In particular, we first follow and extend the work of Chimeli and Boyd (2010) and present evidence that large scale mahogany trade persisted after prohibition, through misclassification of mahogany exports as exports of "other tropical timber species." Second, we document relative increases in homicide rates after prohibition in: (i) states with higher share of total mahogany exports before prohibition; (ii) states with higher exports of "other tropical timber species" after prohibition; and (iii) municipalities within the area of natural occurrence of mahogany. The municipality results persist if the sample is restricted to states with some natural occurrence of mahogany or even only to the state of Pará, which accounts for more than $70 \%$ of exports in the pre-prohibition period. The increase in violence after prohibition does not seem to be associated with changes in socioeconomic conditions, agricultural activity, modernization and urbanization, or to be related to pre-existing trends in homicide rates. We believe that the evidence presented here constitutes the first documented experience of increase in violence following the transition of a market from legal to illegal.

Our paper is probably most closely related to the literature on illegal drugs and violence. There is a vast literature outside economics with case studies or descriptive analysis of the patterns and incidence of crime and violence among drug users and sellers (see, for example, papers in De La Rosa et al, 1990). In economics, Miron (1999 and 2001) explores time series and cross-country data on enforcement of alcohol and drug policies, and finds a positive correlation between enforcement and homicides. In the first case, the historical experience of the US is analyzed and identification comes entirely from continuous time series variation in enforcement, which is potentially endogenous to violence itself. In the second case, identification comes from cross-sectional country level variation, with a reduced number of countries, so that omitted variables and outliers are serious concerns. Medina and Martínez (2003), on the other hand, use variation in drug prohibition enforcement across Colombian municipalities between 1991 and 1998 and find no systematic relationship between 
enforcement and crime, though again endogeneity may be an issue. More recently, Adda et al (2010) explore an episode of decriminalization of cannabis possession in a London borough between 2001 and 2002. They find that decriminalization was associated with an increase in drug related offenses and a reduction in other types of offenses, as police shifted resources towards non-drug related crimes. In addition, the authors find that there was a reduction in drug related offenses in neighboring boroughs, through relocation of consumers to the decriminalized borough.

As Adda et al (2010), we use an institutional change that can be seen as a natural experiment on the effect of illegality. But, in our case, we analyze the complete shutdown of a market, rather than changes in the criminal status of consumers in a specific location. Therefore, our setting is more adequate for the analysis of the overall effect of prohibition on the incidence of violence. In addition, we analyze the incidence of violence in a market unrelated to "vice" goods (drugs, alcohol, prostitution, etc), so that we immediately separate the effect of prohibition from what a moralistic perspective might see as intrinsic characteristics of the participants in a particular market. Our results suggest that prohibition, per se, is associated with violence.

The remainder of the paper is structured as follows. Section 2 presents a background of mahogany trade and policy in recent decades in Brazil. Section 3 presents the data used in the paper. Section 4 describes our empirical strategy. Section 5 presents the results related to mahogany trade after prohibition. Section 6 presents the results on prohibition of mahogany trade and violence. Finally, section 7 concludes the paper.

\section{Mahogany Policy in Brazil}

Big leaf mahogany (Swietenia macrophylla King) is a native species of the Americas, originally ranging from Mexico to the Amazon region in South America. The durability and color of the timber from this tree are the main reasons for the high prices it fetches in international markets and has led to its intense exploration over the years. Most of the remaining big leaf mahogany trees are located in the Amazon forest, and Brazil was the largest exporter of the species prior to prohibition of production and trade by the local government in 2001 . The majority of the Brazilian production of big leaf mahogany was exported and the main 
consumers of the species were the United States and the European high-end furniture and construction markets.

Exploration of Brazilian mahogany in the 1980 s and 1990s contributed to increased concern by domestic and international environmentalists who argued that uncontrolled extraction of the species would soon lead to its extinction. Although this statement has been disputed, ${ }^{2}$ a series of regulations were introduced by the Brazilian government to curb extraction of the species starting in the early 1990s. These included export quotas limiting international sales to $150,000 \mathrm{~m}^{3}, 65,000 \mathrm{~m}^{3}$ and $30,000 \mathrm{~m}^{3}$ in 1990, 1998 and 2001 respectively; moratorium on the issuance of new forest management plans to back up mahogany extraction starting in July 1996; creation of a working group to audit forest management plans (required for mahogany extraction to take place), which led to the suspension of $85 \%$ of all management plans in March 1999; and prohibition of extraction, transportation and domestic or international trade of mahogany in October 2001. Finally, big leaf mahogany was listed on appendix II of the United Nations Convention of International Trade of Endangered Species of Wild Fauna and Flora (CITES) in November 2002 (this regulation came into force in November 2003). Inclusion of a species in appendix II of CITES requires careful monitoring of international trade of the endangered species by both the exporting and importing countries. This, in turn, might have reinforced the impetus for maintaining the more stringent outright prohibition already imposed by Brazilian authorities. ${ }^{3}$ Institutionally, the two main restrictions were those introduced in March 1999 - when 85\% of the management licenses where suspended - and October 2001 - when mahogany extraction was finally prohibited.

Despite tightened regulations of the local mahogany market, mounting evidence suggests the continuing smuggling of big leaf mahogany formally exported under the guise of other species. In a recent article, Chimeli and Boyd (2010) analyze formal export data to show that Brazilian exports under the trade category "other tropical timber species" jumped by $1,800 \%$ in a single month in 1999 and were sustained at volumes comparable to those of former exports of big leaf mahogany. More importantly, they estimate structural breaks in the series for "other tropical timber species" and verify that these regime changes closely match

\footnotetext{
${ }^{2}$ See Roozen (1998) and cited references.

${ }^{3}$ See IBAMA (1999), Grogan et al (2002), and Lentine et al (2003).
} 
regulatory changes in the big leaf mahogany market. An especially strong structural break takes place following the suspension of $85 \%$ of all forest management plans in March 1999. They also explore alternative explanations for the jumps in exports of "other tropical timber species" from Brazil, but only to find further evidence that these exports actually correspond to smuggling of big leaf mahogany through formal export channels.

To briefly describe how mahogany can be smuggled out of the country through formal export channels, we first note that the main timber species exported from the Amazon are mahogany, Brazilian cedar, ipe, virola-balsa and louro. These species have separate international trade codes that exporters have to specify when they sell their product (Common Mercosur Nomenclature - NCM, chapter 44). In addition to these, there is an aggregate trade code that encompasses "other tropical timber species" (NCM 4407.29.90).

An exporter has to either directly register with the Brazilian revenue service ("Receita Federal") as an exporter, or hire an export company to perform the international trade on its behalf. At this stage, the exporter has to produce an invoice specifying the quantity and value of the transaction to be made and additionally fill out two export forms ("Registro de Exportação," RE, and "Declaração de Despacho de Exportação," DDE). Both the RE and the DDE have to specify the NCM code of the exported merchandize, and this is the point at which the exporter has the opportunity to list their mahogany as another species. Finally, the exporter is required to hire a customs dispatcher, who, by law, has to be outsourced and cannot be on the payroll of an exporter. The dispatcher is then responsible for presenting the cargo at the port.

While import tariffs are common in Brazil, there presently exists no export tax. As a result, the likelihood of inspection at the port ("yellow light" or "red light" levels of monitoring) is much lower for exports than for imports. This arrangement gives exporters an opportunity to smuggle mahogany as a different species (which is subject to less stringent regulations). Once mahogany is smuggled, the exporter is paid the invoice value through the formal export procedures, and the importer obtains a cargo complete with formal documentation.

Figure 1 presents the aggregate series for Brazil of mahogany and "other tropical timber species" exports, between 1989 and 2009. It is clear that the declining trend of mahogany exports after the introduction of restrictions is accompanied by a rising trend in the export of 
"other tropical timber species." ${ }^{4}$ In order to illustrate this point, the figure also presents the sum of the two series, which displays a surprisingly stable pattern. The aggregate series do suggest that legal mahogany exports were replaced by illegal exports under the guise of "other tropical timber species." Prior accounts by Blundell and Rodan (2003), Barreto and Souza (2001), and Gerson (2000) describe this same phenomenon. Apprehensions from as recently as early 2010 provide additional anecdotal evidence that Brazilian mahogany was systematically exported as species falling under the general category "other tropical timber species" (see, for example, Diário do Pará, 2010).

The existing evidence suggests that regulations that significantly reduced exports of big leaf mahogany and finally culminated into outright prohibition of the mahogany market in Brazil have contributed to the creation of an active illegal market. Grogran et al (2002) estimate the total value of mahogany exports between 1971 and 2001 to be around US\$ 4 billion. In order to highlight the relevance of this potential market to the local economy of the Amazon, notice that this total value averages US\$ 129 million per year, corresponding to $1.2 \%$ of the aggregate GDP for the state of Pará in year 2000 (Pará accounted for more than 70\% of total mahogany exports before prohibition).

Furthermore, the peculiar characteristics of the smuggling of Brazilian mahogany allow us to track this illegal market. To the extent that the crime literature postulates that illegal markets can be linked with increased violence, we have a unique opportunity to test this hypothesis and the magnitude of the resulting effect of prohibition on violence, in case it indeed exists (for a theoretical model, see Donohue and Levitt, 1998; references from the policy and empirical literatures include Nadelmann, 1989, De La Rosa et al, 1990, Miron and Zwiebel, 1995, Miron, 1999 and 2001, and Keefer and Loayza, 2010). Particularly in relation to violence with connection to illegal logging, anecdotal evidence abounds, both in Brazil and elsewhere (see, for example, Greenpeace, 2001 and 2004, and Hance, 2010). It is common to see reports that discuss illegal logging as intrinsically related to the widespread use of violence. ${ }^{5}$

In the following sections, we first test for structural breaks in the exports of "other tropical timber species" in the Brazilian states of Amazonas, Mato Grosso, Pará and Rondônia,

\footnotetext{
${ }^{4}$ Some export of mahogany after prohibition in 2001 is registered, since exports from specimens extracted before prohibition was allowed under certain circumstances.

${ }^{5}$ In fact, Hance's (2010) interview article on Indonesia is titled "Violence a part of the illegal timber trade, says kidnapped activist."
} 
located in the Amazonian region and where mahogany naturally occurs (Grogan et al, 2002). We then compare the estimated breaks with the dates when Brazilian authorities imposed restrictions on the mahogany market. These regime changes can then serve as benchmark dates to test the effect of prohibition on homicides in regions affected by mahogany exploration and trade.

\section{Data}

\section{Mahogany Variables}

In order to conduct our exercises, we need some indicator of the relevance of mahogany in certain areas of the country. We use different pieces of information to construct such indicator. First, Grogan et al (2002), based on Lamb (1966) and on field work conducted by the authors, provide a map indicating the area of natural occurrence of mahogany in the Brazilian territory (the same map is presented by Lentini et al, 2003). Appendix A.1 reproduces the map presented by Grogan et al (2002). We superimpose this map on a map of the political division of Brazil into municipalities and create a dummy variable equal to 1 if a municipality is located within the area of natural occurrence of mahogany. ${ }^{6}$ Using this variable, we also create a state level variable equal to 1 if a given state has at least part of its territory within the area of natural occurrence of mahogany.

Given the difficulty of access in the Brazilian Amazon, where the mahogany occurrence area is concentrated, the former variable may not be a very precise indicator of the actual relevance of mahogany in a certain region. For remote areas, with costly transportation, natural occurrence may not be enough to warrant profitable exploration. So we also construct another variable trying to capture the economic relevance of mahogany in different regions. We have state level information on the total exports of mahogany (in kilograms) before prohibition, starting from 1989. Based on this information, we create a variable indicating the state share in total exports of mahogany before 1999. Exports can be done by a state that does not produce mahogany, in case an exporting company buys wood from a producing state. Still, more than

\footnotetext{
${ }^{6}$ For the state of Pará, the main producer of mahogany before prohibition, Greenpeace (2001) presents a map indicating locations of legal mahogany logging and locations where investigations uncovered illegal mahogany extraction. It is reassuring that these locations are all within the area of natural occurrence of mahogany indicated by our variable and imply an overall distribution of mahogany activity very similar to that suggested by the map from Groggan et al (2002).
} 
$90 \%$ of mahogany exports come from the region of natural occurrence of mahogany, with more than $70 \%$ coming from the state of Pará, which is typically identified as the main producer and the area where most of the illegal logging takes place (see, for example, Greenpeace, 2001).

Finally, in some of our exercises we also use information on exports of "other tropical timber species" by state, available between 1989 and 2009. We use this information to present evidence on the continuing exploration and trade of mahogany after prohibition and, in some robustness exercises, as a proxy for the extent of illegal logging taking place in different states.

The data on exports of mahogany and other type of tropical timber wood come from the Analysis of Information on International Trade ("Análise das Informações de Comércio Exterior" - ALICE-Web, available from aliceweb.desenvolvimento.gov.br) compiled by the Brazilian Secretariat on International Trade (SECEX), Ministry of Development, Industry and International Trade (MDIC). The two export categories we analyze in this paper are monthly exports in $\mathrm{Kg}$ of mahogany and "other tropical timber species" for all exporting states of Brazil, from January 1989 to March 2010. To construct these series we took into account a change in export codes that took place in 1996. The precise strategy we used to match the codes before and after 1996 is described in detail in the Appendix A.2.

\section{Outcome Variable}

Our outcome variable, used as an indicator for the incidence of violence, is the homicide rate per 100,000 inhabitants. This variable is available at the state and municipality levels, on a yearly basis, from the Brazilian Ministry of Health integrated system of information (www.datasus.gov.br). Homicide rates are thought to have a higher reporting rate than other types of violence (Soares, 2004), and the unified system of public health from the Brazilian government warrants a certain uniformity in definition across regions. The homicide data are available yearly since the early 1980 s.

\section{Control Variables}

The choice of control variables is guided by our main empirical concerns, which we discuss in detail in the next section. Our goal is to account for other relevant changes possibly taking place simultaneously and maybe determined by the prohibition of mahogany trade, and which may also affect the incidence of violence.

Most of the state level variables used come from the Brazilian National Household Survey ("Pesquisa Nacional por Amostra de Domicílios" - PNAD) and were tabulated by the 
Institute for Applied Economic Research (“Instituto de Pesquisa Econômica Aplicada” - IPEA, available from www.ipeadata.gov.br), a think tank from the Brazilian government. These include: poverty rate, ratio of income per capita of the top $10 \%$ of the income distribution to the bottom $40 \%$, percentage of households with more than 2 members per room, enrollment rate between ages 7 and 14, percentage of informal workers in the labor force, percentage of population living in households with access to treated water, percentage of population living in households with toilet connected to the public sewerage system, illiteracy rate in the population above 15, percentage of the labor force occupied in agriculture and fishing, and unemployment rate. Other state level data include population projections from the Brazilian Census Bureau ("Instituto Brasileiro de Geografia e Estatística" - IBGE), per capita gdp and percentage of gdp in agriculture from the system of regional accounts of IBGE, total planted area from the municipal agricultural survey from IBGE, and household electricity consumption from the IBGE statistical yearbook (tabulated by IPEA). Some of these variables are also available, for certain years, at the municipality level (gdp per capita, share of agriculture on gdp, and planted area).

The main limitation of the control variables is their yearly coverage, which is limited by the availability of the surveys used to construct the variables. So the variables constructed from the PNAD area available, under a consistent methodology, since 1992, but for the years 1994 and 2000, when the survey did not take place. Household electricity consumption is not available for the year 1997, while the other state level variables are available for all years between 1992 and 2007. Within this time interval, the municipality gdp data is available for 1996 and for 1999-2007, while area planted within the municipality is available for all years.

Given the availability of data, the creation of a large number of municipalities in Brazil in the early 1990s, and the fact that the interventions we want to analyze are introduced only in the end of the 1990s, we restrict our sample to the period between 1995 and 2007. Still, the analyses including all controls loses part of the observations within this time interval (when discussing the results, we mention to what extent eventual changes in results are due to the introduction of controls or to the restriction of the sample).

Tables 1 and 2 and Figure 2 present descriptive statistics for states and municipalities. Table 1 presents averages for states outside the mahogany occurrence areas, states with some mahogany occurrence area, and for the state of Pará separately, given its historical importance 
in mahogany production. Table 2 presents similar descriptive statistics, but organized by municipalities. Table 1 makes clear that mahogany regions are typically poorer, more agricultural, and with less access to public goods than other regions of Brazil. Also, mahogany regions start with lower homicide rates, but converge to the countrywide homicide rates by 2007. Table 2 shows that this pattern is enhanced when we look at the more precise municipality level data, but that if we restrict the analysis to the state of Pará, the differences become milder.

Figure 2 plots the homicides rate series from Tables 1 and 2. The patterns mentioned before become even clearer, and the dates of the main interventions in the prohibition of mahogany do seem to be associated with relative increases in homicide rates in mahogany occurring areas. Particularly striking is the pattern observed in the state of Pará, where the evolution of homicides was identical between mahogany and non-mahogany occurring areas before prohibition, but where a gap opens up immediately after the first major restriction to logging in 1999. Tables 1 and 2 and Figure 2 suggest that prohibition may indeed have had an effect on violence, but they also highlight the challenges implicit in our empirical exercise.

\section{Empirical Strategy}

\subsection{Illegal Mahogany Trade after Prohibition: Structural Break Estimation}

We first provide evidence that exports of mahogany continued after prohibition, through misclassification of mahogany exports as exports of "other tropical timber species." In order to do so, we show that the historical series of exports of other wood experienced astounding increases in quantity (kilograms) following the introduction of the most severe restrictions on mahogany exploration. To develop this argument formally, we test for endogenous structural breaks in the series and check whether the dates identified by the model match the timing of introduction of restrictions in the mahogany market. This same exercise was conducted for the aggregate monthly series for Brazil by Chimeli and Boyd (2010). Here we extend their analysis by looking at exports by state and also by performing the same tests with yearly series (which tend to be less noisy than monthly). 
Consider a step function with $m$ structural breaks determining $m+1$ distinct regimes: ${ }^{7}$

$y_{i t}=\delta_{j}+u_{t}$ with $t=T_{j-1}+1, \cdots, T_{j}$ and $j=1, \cdots, m$,

Where $y_{t}$ is the observed dependent variable, $\delta_{j}$ are regime specific averages (regime specific coefficients of regression of $y_{t}$ on a vector of 1 's), $u_{t}$ is the possibly autocorrelated and heteroskedastic disturbance at time $t$, and $T_{1}, \ldots, T_{m}$ are the break points to be estimated.

Estimation of these breakpoints initially requires calculation of the minimum sum of squared residuals for each admissible partition of the time domain: ${ }^{8}$

$$
S_{T}\left(T_{1}, \cdots, T_{m}\right)=\min _{\delta} \sum_{i=1}^{m+1} \sum_{t=T_{i-1}+1}^{T_{i}}\left(y_{t}-\delta_{i}\right)^{2}
$$

Next, Bai and Perron (1998) use a dynamic programming algorithm to compute the minimum $S_{T}\left(T_{1}, \ldots, T_{m}\right)$ over all admissible partitions, yielding the estimated breakpoints

$$
\left(\hat{T}_{1}, \cdots, \hat{T}_{m}\right)=\operatorname{argmin} T_{T_{1}, \cdots, T_{m}} S_{T}\left(T_{1}, \cdots, T_{m}\right)
$$

Finally, to rigorously determine the number of breaks in the series, we employ a set of statistics derived by Bai and Perron (1998) to first test the null hypothesis of no breaks versus the alternative of $m=b$ breaks, and then to test the null hypothesis of $I$ breaks against $I+1$ breaks.

\subsection{Mahogany Prohibition and Violence: Difference-in-Difference}

The dimensions of variation we explore to identify the causal effect of prohibition on violence are the timing of the institutional changes, and the differential relevance of mahogany

\footnotetext{
${ }^{7}$ Bai and Perron (1998) derive their results in a more general linear framework $y_{t}=x_{t}^{\prime} b+z_{t}{ }^{\prime} \delta_{j}+u_{t}$. However, the step function or breaks in unconditional means is widely applied (see for example, Bai and Perron, 2003 and Rapach and Wohar, 2005) and fits our purposes here, since we have no strong basis or data to further expand our empirical model of exports of "other tropical timber species" at this stage.

${ }^{8}$ By admissible partition of the time domain, we mean partitions $T_{1}, \ldots, T_{m}$ such that each regime lasts for no less than a given pre-determined time length.
} 
across different areas of the country. In principle, if the increase in homicide rates after prohibition is larger in mahogany occurring or producing areas than in other areas, this differential increase could be attributed to prohibition.

The timing of the intervention considered here is unique for the entire country. So identification of the effect of prohibition comes from the heterogeneous response of different areas to prohibition, rather than from differential timing of treatment. Areas with no mahogany related activity should experience no significant changes in the incidence of violence due to prohibition (apart from general equilibrium effects, which are likely to be small), while areas with some type of mahogany activity should experience increases in violence following prohibition.

Given the institutional discussion from section 2 and the evidence to be presented in the next section, we focus on two particular years as key moments in the increasing trend towards mahogany trade prohibition. First, we create a dummy variable equal to 1 for 1999 and all following years, capturing the first major step towards prohibition (suspension of $85 \%$ of the operating licenses for management plans). Following, we create a second dummy variable equal to 1 for 2002 and all following years, corresponding to the final prohibition of mahogany trade instituted in October 2001. When evaluating the impact of prohibition, we estimate the models with each of these variables separately and with both included simultaneously.

Our benchmark specification is the following:

$$
\begin{aligned}
\text { Homicide }_{i t}=\alpha+B_{1} \cdot\left(D_{t \geq 1999} \times \text { Mahog_Var }_{i}\right)+B_{2 \cdot}\left(D_{t \geq 2002} \times \text { Mahog_Var }_{i}\right) \\
\\
+\gamma \cdot X_{i t}+\vartheta_{i}+\mu_{t}+\varepsilon_{i t},
\end{aligned}
$$

where Homicide $_{i t}$ indicates the homicide rate for location (state or municipality) $i$ in year $t$; $D_{t \geq 1999}$ is a dummy variable equal to 1 for 1999 and all following years; $D_{t \geq 2002}$ is a dummy variable equal to 1 for 2002 and all following years; Mahog_Var ${ }_{i}$ is some variable indicating the relevance of mahogany in location $i$ (to be discussed in the next paragraph); $X_{i t}$ is a vector of control variables; $\vartheta_{i}$ is a location fixed-effect; $\mu_{t}$ is a year fixed-effect; $\varepsilon_{i t}$ is a random term; and $\alpha, B_{1}, B_{2}$, and $\gamma$ are parameters. Under the usual assumptions, $E\left[\varepsilon_{i t} \mid D_{t \geq 1999}, D_{t \geq 2002}, M_{a h o g} V_{a r}\right.$, $\left.X_{i t}, \vartheta_{i}, \mu_{t}\right]=0$, and OLS estimation of the equation above provides unbiased estimates of the $B^{\prime}$ s. The source of variation used to identify the effect of the program is the timing of 
implementation and the comparison of municipalities with mahogany activity to municipalities without mahogany activity. In this hypothetical setting, the random term $\varepsilon_{i t}$ is not correlated with the independent variables, so OLS estimates of the $b^{\prime}$ s indeed provide the parameters of interest: the causal impact of mahogany trade restrictions on homicide rates.

We use two sources of information to identify the relevance of mahogany in a given area (Mahog_Var ${ }_{i}$. First, we use information on the area of natural occurrence of mahogany. From that, we create a dummy variable equal to 1 for municipalities that are in the mahogany occurring area, and another dummy variable equal to 1 for states that have at least part of their territory in the area of natural occurrence of mahogany. But natural occurrence of mahogany may not be enough for mahogany trade to be an important activity, given that it may not be economically profitable to explore mahogany in remote and difficult to access areas. So we also use information on mahogany exports before prohibition. This information is only available at the state level, so we create a variable indicating the share of the state in the aggregate mahogany exports between 1989 and 1998. This variable captures export activity, but not necessarily extraction, since non-mahogany producing states can also be exporters (though, in reality, this is a rare event). Since each of the suggested variables has advantages and disadvantages, we use both of them in our analysis. In addition, we go one step further and explore the interaction between the two, creating a treatment variable that is the product of state share in mahogany exports and the dummy variable for mahogany occurrence area. In reality, this treatment variable corresponds to a triple difference in timing of prohibition, natural mahogany occurrence, and relative importance of mahogany activity (share of exports).

In our context, there are two potential problems with the difference-in-difference strategy: omitted variables and differential dynamic behavior of homicide rates. First, there may be other changes taking places simultaneously with prohibition of mahogany trade. In particular, prohibition has economic impacts that may indirectly affect the incidence of violence. We try to control for three dimensions that may be of concern: (i) prohibition of mahogany may reduce income in certain areas and reduce labor market opportunities, so we control for a large set of socioeconomic characteristics (income per capita, unemployment rate, percentage of informal workers, fraction of household with more than 2 members per room, and inequality); (ii) prohibition may be related to changes in the pattern of agricultural activity and this may also be intrinsically related to violence in the agricultural frontier, so we control 
for fraction of area planted, share of agriculture in gdp, and fraction of population occupied in agriculture; and (iii) some of the mahogany areas are remote regions of the country, that may be going through modernization changes and increased urbanization, so we control for access to various public goods (enrollment rate between ages 7 and 14, percentage of population living in households with access to treated water, percentage of population living in households with toilet connected to the public sewerage system, illiteracy rate in the population above 15 , and household electricity consumption per capita).

As discussed in the previous section, most of these variables are available only at the state level, while only some are available (in a much reduced frequency) at the municipality level. Given the relative strengths of the various types of data - more years homogeneously covered, but less precision, for the state level data - we conduct our analysis for different levels of aggregation and using different sets of controls. Also, part of the analysis restricts the sample to municipalities in states with natural occurrence of mahogany, and then only to municipalities in the state of Pará. Treatment and control groups are more homogeneous within these specific areas (see Tables 1 and 2), and the state of Pará is particularly relevant because it accounted for more than $70 \%$ of mahogany exports before prohibition.

The second issue raised before relates to the possibility of differential dynamic behavior

of homicides in mahogany occurring areas, even before the imposition of restrictions on logging and trade. Figure 2 suggests that this did not seem to be the case, but we explore this possibility by estimating the response of homicide rates to placebo treatments before the imposition of the main restrictions on mahogany exploration.

There are some remaining methodological issues that we deal with in our estimation: (i) as the variance of homicide rates is directly related to population size, we weight all regressions by population size; and (ii) as the difference-in-difference strategy may lead to underestimation of standard errors due to autocorrelation in the residuals, we cluster standard errors at either the state or municipality level, allowing for an arbitrary structure of correlation over time (as suggested by Bertrand et al, 2004).

\section{Results: Illegal Mahogany Trade after Prohibition}

Table 3 presents the estimated structural breaks for the series on exports of "other tropical species" for the states of Amazonas, Pará, Mato Grosso, and Rondônia. We concentrate 
on these four states since they are in the area of natural occurrence of mahogany and account for more than $93 \%$ of the overall exports of "other tropical timber species" during the mahogany prohibition period. Figures $3 \mathrm{a}$ and $3 \mathrm{~b}$ plot the corresponding breaks. The results on the left portion of the table are based on monthly export data, whereas the right portion uses total annual exports. Whereas the number of observations is much larger when we use monthly data, higher frequency data can mask longer run movements in the series. We therefore report our results for both the series with more data points (monthly data) and the aggregate series involving larger time spans (one year). Estimated break points appear in bold (month of the year in parenthesis) followed by the corresponding confidence intervals. Since Bai and Perron's (1998) algorithm uses integers for dates, confidence intervals formed by time spans smaller than the time unit of the series are not reported and appear as NA.

The results are quite consistent across data aggregation alternatives with the exception of the state of Amazonas. Visual inspection of the time series for Amazonas suggests a regime change in the volume of exports sometime around the year 2000 or 2001 . This structural break is captured in the annual series, but not in the more volatile monthly series. Furthermore, several of the estimated structural breaks are consistent with the institutional changes affecting the mahogany market.

Prior to prohibition of the mahogany market in October 2001, the state of Pará accounted for $70 \%$ of all exports, followed by Paraná (10\%), Mato Grosso (8\%), Rondônia (6\%), Acre (3\%), São Paulo (2\%) and Amazonas (2\%). ${ }^{9}$ The first structural break for the state of Pará occurs in 1999 , following suspension of $85 \%$ of all forest management plans. These loggers were the largest producers of big leaf mahogany and effectively lost their ability to formally extract and sell this resource. The structural break taking place in Pará in August 1999 accounts for the bulk of the $1,800 \%$ increase in the Brazilian export of other tropical species in one single month. The next structural break that appears in all series occurs sometime between 2002 and 2003. This break is consistent with two institutional changes affecting the mahogany market: i) prohibition of extraction, transportation and trade of big leaf mahogany imposed by Brazilian authorities, and ii) inclusion of big leaf mahogany in appendix II of CITES, which might have signaled that prohibition were likely to be maintained. We therefore find support to the

\footnotetext{
${ }^{9}$ The states of Paraná and São Paulo are outside the area of natural occurrence of big leaf mahogany and their exports corresponds to mahogany timber purchased from exporting sates.
} 
hypothesis that the drastic contraction of the formal mahogany market in 1999 and prohibition in late 2001 have contributed to the flourishing of an illegal market in the main producing states. $^{10}$

Finally, another structural break is estimated to take place between late 2006 and early 2007 in all states. Contrary to the previous regime changes when exports of "other tropical species" increased, the latter regime change suggests a decrease in exports from Pará and Amazonas and an increase in exports from Mato Grosso and Rondônia. Although this structural break might reflect important idiosyncrasies of the mahogany market unknown to us at this point, we choose not to focus on it as a "treatment" date in our homicide analysis, because we cannot directly link this regime switch to clear institutional changes in the mahogany market. In reality, it is likely to be related to changes in enforcement of prohibition and tighter monitoring of smuggling in the more traditional illegal markets.

\section{Results: Mahogany Prohibition and Violence}

\section{State Level Analysis}

Table 4 presents the benchmark results for our state level analysis. The table displays the coefficients estimated with the specification from equation 4, without the inclusion of any control, when the three different treatments are considered: mahogany occurring states interacted with prohibition years, pre-prohibition share of exports interacted with prohibition years, and mahogany occurring states interacted with pre-prohibition share of exports and interacted with prohibition years. For each treatment variable, we consider the changes of regulations that were instituted in 1999 and late 2001 separately, and then simultaneously.

The results show that the coefficients are not statistically significant when we consider states with some mahogany area in the treatment. This is not surprising, since some of these states have very small areas with occurrence of mahogany (less than $1 \%$ in the case of Maranhão and $7 \%$ in the case of Tocantins). So the state level dummy variable of mahogany occurrence has very coarse information. When we consider the pre-intervention exports of mahogany in the treatment variable, either interacted with the time of treatment or with time

\footnotetext{
${ }^{10}$ When analyzing total Brazilian exports of "other tropical timber species" to the European Union and the United States for the time span ranging from January 1989 to December 2006, Chimeli and Boyd (2010) estimate structural breaks in August 1999 and sometime in the time span ranging from September 2002 to April 2004, depending on the consumer market and taking into account estimated confidence intervals.
} 
of treatment and mahogany occurring areas, the results turn out to be significant. Looking at the 1999 or the 2002 interventions separately, they are positive and statistically significant, but when both of them are included simultaneously, only the 2002 intervention remains significant. The model is unable to separately identify the effect of each intervention.

Table 5 shows that this same qualitative patterns remains when we include our full set of economic, agricultural activity, and access to public goods controls, despite the fact that we lose two years of observations. If anything, point estimates on the effect of the 2002 ban on mahogany trade become larger than those reported in Table 4.

One concern in these specifications is that mahogany states are intrinsically different from other states, and the treatment variable may be only capturing the distinct dynamic of violence in these regions. If this was the case, one would expect this distinct dynamic to be present already before the restrictions on mahogany exploration and trade. To assess this possibility, Table 6 estimates the specifications from columns 3, 6, and 9 from Table 4 introducing variables trying to capture pre-intervention placebo treatments. ${ }^{11}$ The placebos are, according to the treatment variable used in each specification, a dummy for 1997-1998 interacted with: mahogany occurring states, pre-1999 share of mahogany exports, and the interaction of these two variables. The estimated coefficients on the pre-intervention placebo variables are small in magnitude and far from significant in all cases. The coefficients on the treatment variables remain almost identical to those reported in Table 4.

One might ponder that, if the results from section 5 and from this section are correct, than it should be expected that homicides after prohibition would be correlated with state level exports of "other tropical timber species." If exports of "other tropical timber species" are capturing illegal activity and the increase in violence is indeed related to illegality, then this correlation should be expected. As a final exercise in the state level analysis, we consider explicitly this possibility. We consider as treatment variables the interaction of exports of other wood (which changes yearly) with the dummy variables indicating the intervention years, and also the triple interaction of these two variables with mahogany occurring states. In Table 7, we present the results of estimations with these treatment variables, with and without controls,

\footnotetext{
${ }^{11}$ We conduct the placebo exercises with the specification without controls since it has a more complete sample in terms of year coverage. The results on the placebo effects are identical when we include the controls, but since in this case the data is not well balanced across years, we think it is actually a weaker test.
} 
and also checking for placebo effects. Qualitative results are identical to those obtained before, when we considered the exports of mahogany before prohibition in the treatment. Since here we are using yearly export data that are available before and after prohibition, our placebo exercise is even stronger. Our pre-treatment placebo variables are simply an interaction of yearly exports of other wood with a pre-1999 dummy (column 7) and an interaction of these two variables with mahogany occurring states (column 8). Both pre-intervention variables are not statistically significant, and the post-intervention treatments remain with very similar coefficients. In other words, exports of "other tropical timber species" are significantly correlated with homicide rates after 1999 or after 2002, but not before. With the inclusion of controls (columns 9 to 14), point estimates on treatment variables become larger in magnitude, also as noticed before.

\section{Municipality Level Analysis}

There are two problems with the use of state level data: it potentially hides a lot of unobserved heterogeneity and the measure of occurrence of mahogany is very coarse. A municipality level analysis can therefore use a more precise measure of mahogany occurrence and deal better with the comparability of treatment and control groups. But this comes at the expense of the availability of fewer controls, with more irregular yearly coverage.

We start in Tables 8 and 9 simply trying to reproduce Tables 4 and 5 with the municipality dataset. So the treatments here are interactions of the post-1999 and post-2002 dummies with: a dummy indicating whether a municipality is in the area of natural occurrence of mahogany, a variable indicating the pre-1999 state share in mahogany exports, and the interaction of these two variables. The real differences here are that we are using municipality data and that the variable indicating mahogany occurrence is much more precise than that used at the state level.

Table 8 shows that the results using only the mahogany occurrence variable (columns 1 to 3 ) become quantitatively stronger and statistically significant when we use the more precise municipality level variable. Results using pre-1999 exports of mahogany (columns 4 to 6) are almost identical to those obtained before, both in terms of estimated coefficients and significance (we cluster standard errors at the state level in this specification, as opposed to municipality in the other ones, since here the variation in treatment is at the state level). The triple difference (columns 7 to 8 ) leads to results that are qualitatively similar but quantitatively 
stronger than those obtained in Table 4. In Table 9, we introduce municipality and state level controls and, despite a substantial loss in number of observations (we lose roughly 4 years of data on more than 5,000 municipalities), qualitative and quantitative results remain very similar to those from Table 8.

Following, we restrict the sample in two different ways to deal with potential concerns related to the comparability of treatment and control groups. First, we restrict the sample to states with some natural occurrence of mahogany, so that we end up with only 7 states. We then estimate equation 4 using only the dummy for municipalities with natural occurrence of mahogany in the treatment, and the interaction of this variable with the pre-1999 state share in mahogany exports. Results are presented in Table 10. When we consider just the mahogany area in the treatment, without including controls, the results are somewhat weaker than those obtained before. But either when we introduce controls or when we use the triple difference as treatment, results are again very similar to those from Tables 8 and 9. Even within mahogany occurring states, mahogany occurring areas experience significant increases in violence when compared to other areas.

In Table 11 we go one step further and restrict the sample only to the state of Pará. Given that Pará accounted for most of the mahogany production before prohibition, and that a major part of the illegal activity is thought to take place there, it deserves particular attention. In addition, Table 2 and Figure 2 showed that there is much less municipality heterogeneity within Pará than across Brazil as a whole, so that this exercise may help diminish concerns related to heterogeneity between treatment and control. Given that we are restricting the analysis to a single state, all we can do is compare municipalities inside and outside the area of natural occurrence of mahogany, before and after the institutional changes. Results are presented in Table 11. These results are comparable to columns 1 to 3 in Tables 8 and 9, and columns 1 to 6 in Table 10. The same pattern once more arises and, if anything, point estimates are larger than before. Looking only at the state of Pará, we are still able to detect a statistically significant increase in homicide rates in mahogany occurring areas when compared to other areas.

The estimated coefficients are very large. The coefficient from column 5 in Table 11, for example, implies an increase in homicide rates in mahogany occurring areas of Pará of the order of 74\%, when compared to the 1995 average. But put in perspective of the recent 
experience of the state, this number sounds quite reasonable. In particular, the estimated coefficient explains $58 \%$ of the differential increase in homicide rates between mahogany and non-mahogany occurring areas of Pará, illustrated before in Figure 2(c). The reality is that the state started the period with relatively low incidence of violence, but ended it as a very violent area. Since the mahogany market is estimated to correspond roughly to $1 \%$ of its yearly GDP, it does not seem absurd to suggest that a significant part of the increase in violence was due to illegal logging and the context of violence that followed.

As a final exercise, Table 12 conducts some robustness tests with pre-intervention placebos, similar to those presented in Table 6 for the case of state level data. The placebos considered are interactions of a dummy variable for years 1997-1998 with: mahogany occurring area dummy, average mahogany exports pre-1999, and the interaction of these two variables. To conduct the placebo exercises with the most complete time series possible, we drop the controls. The estimated coefficients on treatment variables remain very similar to those presented before, and none of the placebo treatments appear as statistically significant. So there is no evidence that our treatment variables are capturing differential dynamic behavior of homicide rates that were already present before the introduction of restrictions to mahogany trade.

\section{Concluding Remarks}

This paper presents evidence on the rise in homicide rates in Brazilian regions with natural occurrence or trade of mahogany, following the introduction of increasingly restrictive regulations and eventual prohibition of mahogany exploration. Much has been said in the popular press and in the academic literature about the intrinsic association between market illegality and the use of violence as a competitive strategy. Still, there is very little if any direct evidence on the causal effect of market illegality on violence. We present what we believe is the first piece of evidence on the increase in violence following the complete shutdown of a legal market. The increase in homicides we document is not related to changes in socioeconomic conditions, pre-existing trends in violence, or pernicious or degrading effects of the consumption of the good itself. Our evidence points to a causal effect of market illegality, per se, on the incidence of violence. 


\section{References}

Adda, Jérôme, Brendon Mcconnell, and Imran Rasul (2010). "Crime and the Decriminalization of Cannabis: Evidence from a Localized Policing Experiment." Unpublished manuscript, University College London.

Bai, J. and P. Perron (1998). Estimating and Testing Linear Models with Multiple Structural Changes. Econometrica, 66, 47-68.

Barreto, P. and C. Souza Jr. (2001). Controle do Desmatamento e da Exploração de Madeira da Amazônia: Diagnóstico e Sugestões. Ministério do Meio Ambiente. Instituto Brasileiro de Recursos Naturais Renováveis. PPG7/Promanejo. Relatório técnico, componente III.

Bertrand, Marianne, Esther Duflo, and Sendhil Mullainathan (2004). How Much Should We Trust Differences-in-Differences Estimates? Quarterly Journal of Economics, 119(1), 249275.

Blundell, A. and B. Rodan (2003). Mahogany and CITES: Moving Beyond the Veneer of Legality. Oryx, 37(1), 85-90.

Chimeli, Ariaster B. and Roy G. Boyd (2010). Prohibition and the Supply of Brazilian Mahogany. Land Economics, 86(1), 191-208.

De La Rosa, Mario, Elizabeth Y. Lambert, and Bernard Gropper (1990). Drugs and Violence: Causes, Correlates, and Consequences. NIDA Research Monograph 103, US Department of Health and Public Services, Rockville, 293p.

Diário do Pará (2010). “Operação do IBAMA Apreende $60 \mathrm{~m}^{3}$ de Mogno em Belém." Diário do Pará, published on April 13, 2010.

Donohue, John J. and Steven D. Levitt (1998). Guns, Violence, and the Efficiency of Illegal Markets. American Economic Review Papers and Proceedings, 88(2), 463-467.

Fagan, Jeffey and Ko-lin Chin (1990). Violence as Regulation and Social Control in the Distribution of Crack. In: Mario De La Rosa, Elizabeth Y. Lambert, and Bernard Gropper (eds). Drugs and Violence: Causes, Correlates, and Consequences. NIDA Research Monograph 103, US Department of Health and Public Services, Rockville, 8-43.

Gerson, H. (2000). "An Investigation of the Tropical Timber Trade in Canada with Emphasis on the Compliance, Reporting and Effectiveness of Legislation and Regulatory Procedures for CITES-Listed Timber Species". Unpublished report, Canada Customs and Revenue Agency, London, Canada.

Greenpeace (2001). Partners in Mahogany Crime: Amazon at the Mercy of "Gentlemen's Agreements." Greenpeace, Amsterdam, 18p.

Greenpeace (2004). "Pará: Estado de Conflito." Sumário Executivo, 4p.

Grogan, James, Paulo Barreto, and Adalberto Veríssimo (2002). Mahogany in the Brazilian Amazon: Ecology and Perspectives on Management. IMAZON, Belém, 40p.

Hance, Jeremy (2010). Violence a part of the illegal timber trade, says kidnapped activist - An interview with Faith Doherty. Mongabay.com, July 07, 2010.

IBAMA (1999). Grupo de Trabalho do Mógno. Diren/Deref Brasília, DF, Brasil. Relatório técnico.

Keefer, Philip and Norman Loayza (2010). Innocent Bystanders: Developing Countries and the War on Drugs. Palgrave Macmillan and the World Bank, New York, 362p. 
Lamb, F. Bruce (1966). Mahogany of Tropical America: Its Ecology and Management. The University of Michigan Press, Ann Arbor, 22p.

Lentini, Marco, Adalberto Veríssimo, and Leonardo Sobral (2003). Fatos Florestais da Amazônia 2003. IMAZON, Belém, 110p.

Jayachandran, Seema and Adriana Lleras-Muney (2009). Longevity and Human Capital Investments: Evidence from Maternal Mortality Declines in Sri Lanka. Quarterly Journal of Economics, 124(1), 349-397.

Jayachandran, Seema, Adriana Lleras-Muney, and Kimberly V. Smith (2010). Modern Medicine and the 20th Century decline in Mortality: New Evidence on the Impact of Sulfa Drugs. American Economic Journal: Applied Economics, 2(2), 118-146.

Medina, Carlos and Hermes Martínez (2003). "Violence and Drug Prohibition in Colombia." Facultad de Economía, Universidad de los Andes, Working Paper no.32.

Mieczkowski, Tom (1990). The Operational Styles of Crack Houses in Detroit. In: Mario De La Rosa, Elizabeth Y. Lambert, and Bernard Gropper (eds). Drugs and Violence: Causes, Correlates, and Consequences. NIDA Research Monograph 103, US Department of Health and Public Services, Rockville, 60-91.

Miron, Jeffrey A. (1999). Violence and the U.S. Prohibitions of Drugs and Alcohol. American Law and Economics Review, 1(1), 78-114.

Miron, Jeffrey A. (2001). Violence, Guns, and Drugs: A Cross-Country Analysis. Journal of Law and Economics, 44(S2), 615-633.

Miron, Jeffrey A. and Jeffrey Zwiebel (1995). The Economic Case against Drug Prohibition. Journal of Economic Perspectives, 9(4), 175-192.

Nadelmann, Ethan A. (1989). Drug Prohibition in the United States: Costs, Consequences, and Alternatives. Science, 245(4921), 939-947.

Rapach, David E. and Mark E. Wohar (2005). Regime Changes in International Real Interest Rates: Are They a Monetary Phenomenon? Journal of Money, Credit, and Banking, 37(5), 887-906.

Roozen, T. (1998). A case of need: The struggle to protect Bigleaf Mahogany. Natural Resources Journal, 38, 603-633.

Soares, Rodrigo R. (2004). Development, Crime, and Punishment: Accounting for the International Differences in Crime Rates. Journal of Development Economics, 73(1), 155184. 


\section{Appendix}

A.1 Area of Natural Occurrence of Mahogany in the Brazilian Territory, according to Grogan et al (2002)

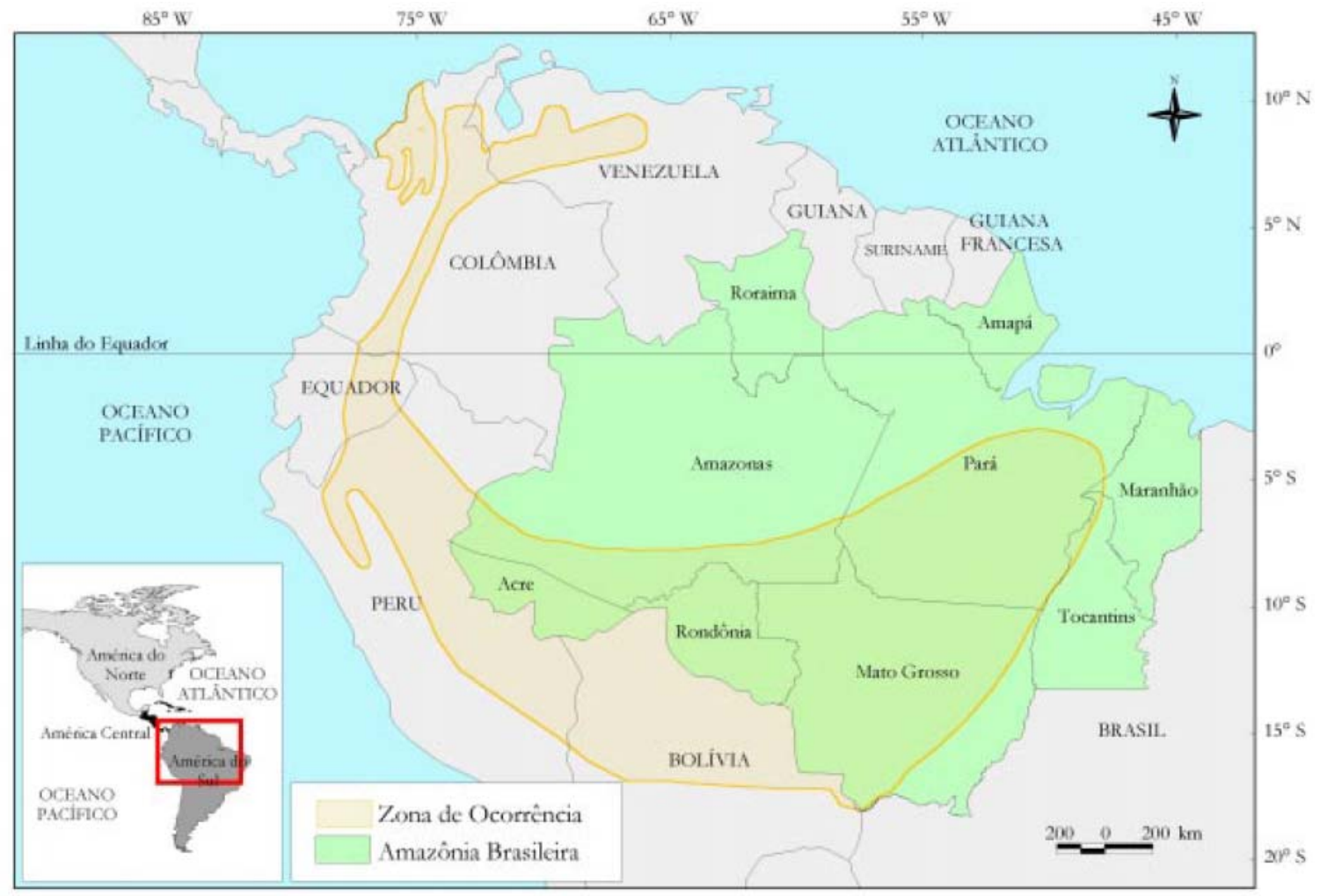




\section{A.2 Construction of Export Series}

Between January 1989 and December 1995, the Brazilian government used the Brazilian Merchandise Nomenclature (NBM) to code products internationally traded. In January 1996, Brazil started adopting the Mercosur Merchandise Nomenclature (NCM) also used by Argentina, Paraguay and Uruguay. Since most merchandise codes were either consolidated or expanded in the new classification system, MDIC then compiled a list to convert NBM into NCM codes. We used this list to construct our series.

International trade data were reported using both systems in 1996 and we used monthly data for this year to check for possible discrepancies associated with the two classification systems. The case of mahogany exports was straightforward (4407.24.10 in the NCM system corresponds to 4407.23.0102 and 4407.23.0201 in the NBM system) with no discrepancies in 1996. As for other tropical species, exports according to the NCM system (4407.29.90) do not match the summation of the corresponding NBM codes in 1996 (4407.21.0100, 4407.21.0200, 4407.21.9900, 4407.22.0100, 4407.22.0200, 4407.22.9900, 4407.23.0199 and 4407.23.0299). Exports of other tropical species in 1996 according to the NCM system were nil for all Brazilian states, whereas they were positive for parts of the year according to the NBM system. The states that had positive exports were Amazonas, Mato Grosso and Pará, all of them in the Amazon region and with parts of their territory overlapping the area where big leaf mahogany naturally occurs. Their joint exports totaled 1,595,578 $\mathrm{Kg}$ in 1996, corresponding to about $2.4 \%$ of the annual average for these states between 1989 and 2009. Visual inspection of the data suggests structural breaks in the exports of other tropical species starting in 1999. Since we build our series using the summation of NBM codes prior to 1997, we err on the safe side and make the test for structural breaks more stringent. 
Table 1: Descriptive Statistics, Brazilian States

\begin{tabular}{|c|c|c|c|c|c|c|c|c|c|c|c|c|}
\hline \multirow[t]{2}{*}{ year } & \multicolumn{4}{|c|}{$\begin{array}{l}\text { States outside Mahogany Occurrence Area } \\
\qquad(\mathrm{N}=20)\end{array}$} & \multicolumn{4}{|c|}{$\begin{array}{l}\text { States with some Mahogany Occurrence Area } \\
\qquad(\mathrm{N}=7)\end{array}$} & \multicolumn{4}{|c|}{ Pará } \\
\hline & $\begin{array}{l}\text { homicides } \\
\text { (per 100,000) }\end{array}$ & $\begin{array}{c}\text { gdp p.c. } \\
(1,000 \text { s in } 2000 \\
\text { R\$ })\end{array}$ & $\begin{array}{l}\text { gdp agric } \\
(\%)\end{array}$ & $\begin{array}{l}\text { access water } \\
(\%)\end{array}$ & $\begin{array}{l}\text { homicides } \\
\text { (per 100,000) }\end{array}$ & $\begin{array}{c}\text { gdp p.c. } \\
(1,000 \text { s in } 2000 \\
\text { R\$) }\end{array}$ & $\begin{array}{l}\text { gdp agric } \\
(\%)\end{array}$ & $\begin{array}{l}\text { access water } \\
(\%)\end{array}$ & $\begin{array}{l}\text { homicides } \\
\text { (per 100,000) }\end{array}$ & $\begin{array}{c}\text { gdp p.c. } \\
(1,000 \text { in } 2000 \\
R \$)\end{array}$ & $\begin{array}{l}\text { gdp agric } \\
(\%)\end{array}$ & $\begin{array}{l}\text { access water } \\
(\%)\end{array}$ \\
\hline 1995 & 25.06 & 6.53 & $8.8 \%$ & $81.1 \%$ & 14.28 & 3.25 & $18.7 \%$ & $52.8 \%$ & 12.76 & 3.26 & $27.9 \%$ & $52.6 \%$ \\
\hline 1996 & 26.08 & 6.62 & $8.3 \%$ & $84.1 \%$ & 14.76 & 3.35 & $18.2 \%$ & $59.7 \%$ & 12.48 & 3.12 & $24.5 \%$ & $60.5 \%$ \\
\hline 1997 & 26.70 & 6.81 & $7.7 \%$ & $83.8 \%$ & 15.49 & 3.30 & $16.9 \%$ & $58.9 \%$ & 13.20 & 3.02 & $22.0 \%$ & $60.1 \%$ \\
\hline 1998 & 27.18 & 6.76 & $7.8 \%$ & $85.1 \%$ & 16.73 & 3.28 & $15.3 \%$ & $61.3 \%$ & 13.33 & 3.00 & $22.1 \%$ & $58.5 \%$ \\
\hline 1999 & 27.75 & 6.52 & $7.6 \%$ & $86.2 \%$ & 14.99 & 3.19 & $16.9 \%$ & $62.7 \%$ & 10.82 & 2.88 & $23.6 \%$ & $64.0 \%$ \\
\hline 2000 & 28.01 & 6.84 & $7.4 \%$ & . & 17.07 & 3.42 & $16.3 \%$ & . & 13.02 & 3.01 & $21.9 \%$ & . \\
\hline 2001 & 29.06 & 6.72 & $7.8 \%$ & $87.9 \%$ & 18.66 & 3.43 & $16.1 \%$ & $65.0 \%$ & 15.06 & 3.10 & $22.1 \%$ & $66.8 \%$ \\
\hline 2002 & 29.66 & 7.37 & $6.1 \%$ & $89.1 \%$ & 19.75 & 3.89 & $14.4 \%$ & $69.3 \%$ & 18.38 & 3.25 & $11.3 \%$ & $69.6 \%$ \\
\hline 2003 & 29.88 & 7.32 & $6.7 \%$ & $89.7 \%$ & 21.36 & 4.07 & $15.3 \%$ & $69.3 \%$ & 21.35 & 3.25 & $10.6 \%$ & $68.7 \%$ \\
\hline 2004 & 27.53 & 7.59 & $6.1 \%$ & $90.7 \%$ & 20.19 & 4.50 & $14.6 \%$ & $63.6 \%$ & 22.17 & 3.51 & $8.2 \%$ & $59.5 \%$ \\
\hline 2005 & 26.23 & 7.72 & $5.1 \%$ & $91.0 \%$ & 23.14 & 4.50 & $13.9 \%$ & $66.9 \%$ & 27.63 & 3.54 & $8.1 \%$ & $60.6 \%$ \\
\hline 2006 & 26.64 & 7.93 & $5.0 \%$ & 91.9\% & 24.28 & 4.50 & $12.5 \%$ & 71.4\% & 29.14 & 3.70 & $8.3 \%$ & $64.7 \%$ \\
\hline 2007 & 26.02 & 8.74 & $4.9 \%$ & $92.8 \%$ & 25.26 & 5.00 & $13.1 \%$ & $72.3 \%$ & 31.04 & 4.01 & $7.7 \%$ & $69.1 \%$ \\
\hline
\end{tabular}

Obs.: Averages weighted by state population. Variables are homicide rates per 100,000 inhabitants, gdp per capita in $2000 \mathrm{R} \$$ (in thousands), percentage of gdp in agriculture, and percentage of individuals living in households with access to treated water. 
Table 2: Descriptive Statistics, Brazilian Municipalities

\begin{tabular}{|c|c|c|c|c|c|c|}
\hline \multirow[b]{3}{*}{ year } & \multicolumn{6}{|c|}{ ALL STATES } \\
\hline & \multicolumn{3}{|c|}{$\begin{array}{c}\text { Municipalities outside Mahogany } \\
\text { Occurrence Area (N=193) }\end{array}$} & \multicolumn{3}{|c|}{$\begin{array}{l}\text { Municipalities inside Mahogany Occurrence } \\
\text { Area }(\mathrm{N}=5364)\end{array}$} \\
\hline & $\begin{array}{l}\text { homicides } \\
\text { (per 100,000) }\end{array}$ & $\begin{array}{c}\text { gdp p.c. } \\
(1,000 \text { s in } 2000 \\
R \$)\end{array}$ & $\begin{array}{l}\text { gdp agric } \\
\text { (\%) }\end{array}$ & $\begin{array}{l}\text { homicides } \\
\text { (per 100,000) }\end{array}$ & $\begin{array}{c}\text { gdp p.c. } \\
(1,000 \text { s in } 2000 \\
R \$)\end{array}$ & $\begin{array}{l}\text { gdp agric } \\
\quad(\%)\end{array}$ \\
\hline 1995 & 24.37 & . & . & 19.14 & . & . \\
\hline 1996 & 25.08 & 6.11 & $18.3 \%$ & 18.85 & 2.54 & $32.0 \%$ \\
\hline 1997 & 25.73 & . & . & 20.50 & . & . \\
\hline 1998 & 26.24 & . & . & 23.08 & . & . \\
\hline 1999 & 26.55 & 6.70 & $9.8 \%$ & 21.52 & 3.43 & $20.9 \%$ \\
\hline 2000 & 27.02 & 6.72 & $10.1 \%$ & 25.09 & 3.51 & $21.6 \%$ \\
\hline 2001 & 28.09 & 6.68 & $10.2 \%$ & 27.91 & 3.57 & $21.1 \%$ \\
\hline 2002 & 28.65 & 7.12 & $9.6 \%$ & 31.58 & 3.75 & $23.2 \%$ \\
\hline 2003 & 29.06 & 7.10 & $10.2 \%$ & 31.90 & 3.96 & $23.7 \%$ \\
\hline 2004 & 27.10 & 7.41 & $9.6 \%$ & 32.26 & 4.36 & $21.9 \%$ \\
\hline 2005 & 25.90 & 7.43 & $8.4 \%$ & 31.99 & 4.40 & $21.7 \%$ \\
\hline 2006 & 26.36 & 7.62 & $8.2 \%$ & 33.30 & 4.37 & $20.5 \%$ \\
\hline \multirow[t]{3}{*}{2007} & 25.27 & 8.14 & $8.1 \%$ & 30.82 & 4.71 & $20.1 \%$ \\
\hline & \multicolumn{6}{|c|}{ PARÁ } \\
\hline & \multicolumn{3}{|c|}{$\begin{array}{l}\text { Municipalities outside Mahogany } \\
\text { Occurrence Area }(\mathrm{N}=90)\end{array}$} & \multicolumn{3}{|c|}{$\begin{array}{l}\text { Municipalities inside Mahogany Occurrence } \\
\text { Area }(\mathrm{N}=53)\end{array}$} \\
\hline year & $\begin{array}{l}\text { homicides } \\
\text { (per } 100,000)\end{array}$ & $\begin{array}{c}\text { gdp p.c. } \\
(1,000 \text { s in } 2000 \\
\text { R\$) }\end{array}$ & $\begin{array}{l}\text { gdp agric } \\
\text { (\%) }\end{array}$ & $\begin{array}{l}\text { homicides } \\
\text { (per } 100,000)\end{array}$ & $\begin{array}{c}\text { gdp p.c. } \\
(1,000 \text { s in } 2000 \\
R \$)\end{array}$ & $\begin{array}{l}\text { gdp agric } \\
(\%)\end{array}$ \\
\hline 1995 & 13.27 & . & . & 12.72 & . & · \\
\hline 1996 & 12.46 & 2.77 & $29.6 \%$ & 12.82 & 1.88 & $39.7 \%$ \\
\hline 1997 & 13.44 & . & . & 12.99 & . & . \\
\hline 1998 & 14.08 & . & . & 11.65 & . & . \\
\hline 1999 & 9.40 & 3.03 & $13.4 \%$ & 15.30 & 2.82 & $25.6 \%$ \\
\hline 2000 & 10.71 & 3.09 & $13.4 \%$ & 20.27 & 3.02 & $26.9 \%$ \\
\hline 2001 & 13.24 & 3.27 & $13.2 \%$ & 20.94 & 3.11 & $25.7 \%$ \\
\hline 2002 & 15.66 & 3.35 & $13.5 \%$ & 26.98 & 3.16 & $26.6 \%$ \\
\hline 2003 & 17.94 & 3.30 & $13.0 \%$ & 30.80 & 3.31 & $24.7 \%$ \\
\hline 2004 & 18.18 & 3.52 & $11.1 \%$ & 36.69 & 3.78 & $20.7 \%$ \\
\hline 2005 & 24.66 & 3.44 & $10.7 \%$ & 37.21 & 3.80 & $20.2 \%$ \\
\hline 2006 & 26.09 & 3.58 & $11.5 \%$ & 38.93 & 4.05 & $20.6 \%$ \\
\hline 2007 & 26.49 & 3.78 & $10.5 \%$ & 42.72 & 4.27 & $19.3 \%$ \\
\hline
\end{tabular}

Obs.: Averages weighted by municipality population. Variables are homicide rates per 100,000 inhabitants, gdp per capita in $2000 \mathrm{R} \$$ (in thousands), and percentage of gdp in agriculture. Top panel includes all municipalities in Brazil, bottom panel includes only municipalities in the state of Pará. 
Table 3: Breakpoints in exports of "other tropical species" for mahogany esporting states

\begin{tabular}{|c|c|c|c|c|c|c|c|}
\hline \multicolumn{4}{|c|}{ Monthly exports } & \multicolumn{4}{|c|}{ Annual exports } \\
\hline \multirow[t]{5}{*}{ Amazonas } & & & & Amazonas & & & \\
\hline & Break Dates & $95 \%$ Cor & nce Interval & & Break Dates & $95 \%$ & nfidence Interva \\
\hline & & & & & 2000 & NA & NA \\
\hline & $2003(4)$ & $2002(6)$ & $2003(5)$ & & 2003 & 2002 & 2005 \\
\hline & $2006(8)$ & NA & NA & & 2006 & 2005 & 2007 \\
\hline \multirow[t]{4}{*}{ Mato Grosso } & & & & Mato Grosso & & & \\
\hline & Break Dates & $95 \%$ Cor & nce Interval & & Break Dates & $95 \%$ & nfidence Interva \\
\hline & $2002(6)$ & $2002(1)$ & $2002(7)$ & & 2002 & 1997 & 2003 \\
\hline & 2006(9) & $2006(5)$ & $2006(10)$ & & 2006 & 2003 & 2007 \\
\hline \multirow[t]{5}{*}{ Pará } & & & & Pará & & & \\
\hline & Break Dates & $95 \%$ Cor & nce Interval & & Break Dates & $95 \%$ & nfidence Interva \\
\hline & 1999(8) & NA & NA & & 1998 & NA & NA \\
\hline & $2003(6)$ & $2003(4)$ & $2003(10)$ & & 2002 & 2001 & 2003 \\
\hline & $2007(1)$ & $2006(5)$ & $2007(3)$ & & 2006 & 1997 & 2007 \\
\hline \multirow[t]{4}{*}{ Rondonia } & & & & Rondonia & & & \\
\hline & Break Dates & $95 \%$ Cor & nce Interval & & Break Dates & $95 \%$ & nfidence Interva \\
\hline & $2003(3)$ & $2002(12)$ & $2003(4)$ & & 2002 & 2001 & 2003 \\
\hline & $2006(8)$ & $2006(2)$ & $2006(10)$ & & 2006 & 2004 & 2007 \\
\hline
\end{tabular}

Obs: Variable is export of other tropical timber species. Series cover the period from 1989 to 2010. Table reports the results of the Bai and Perron (1998) structural break test, with estimated break dates and respective confidence intervals. 
Table 4: Illegality of Mahogany Trade and Homicides, Brazilian States, 1995-2007, Difference-in-difference

\begin{tabular}{|c|c|c|c|c|c|c|c|c|c|}
\hline \multirow[t]{2}{*}{ Treatment: } & \multicolumn{3}{|c|}{ Mahog State x Treat Years } & \multicolumn{3}{|c|}{$\begin{array}{c}\text { Pre-1999 Mahog Exp x Treat } \\
\text { Years }\end{array}$} & \multicolumn{3}{|c|}{$\begin{array}{c}\text { Mahog State x Pre-1999 Mahog } \\
\text { Exp x Treat Years }\end{array}$} \\
\hline & 1 & 2 & 3 & 4 & 5 & 6 & 7 & 8 & 9 \\
\hline \multirow[t]{2}{*}{ treat 1999} & 3.689 & & -0.463 & $10.41^{* *}$ & & -1.984 & $9.285^{* *}$ & & -2.273 \\
\hline & [2.861] & & [1.967] & {$[4.030]$} & & [2.629] & {$[3.446]$} & & [2.292] \\
\hline \multirow[t]{2}{*}{ treat 2002} & & 5.813 & 6.069 & & $16.94 * *$ & $18.04 * *$ & & $15.56 * *$ & $16.81 * *$ \\
\hline & & {$[4.796]$} & [5.439] & & {$[6.216]$} & {$[6.851]$} & & [5.618] & [6.310] \\
\hline Observations & 351 & 351 & 351 & 351 & 351 & 351 & 351 & 351 & 351 \\
\hline R-squared & 0.828 & 0.831 & 0.831 & 0.829 & 0.833 & 0.833 & 0.829 & 0.832 & 0.832 \\
\hline
\end{tabular}


Table 5: Illegality of Mahogany Trade and Homicides, Controls Included, Brazilian States, 1995-2007, Difference-in-difference

\begin{tabular}{|c|c|c|c|c|c|c|c|c|c|}
\hline \multirow[t]{2}{*}{ Treatment: } & \multicolumn{3}{|c|}{ Mahog State $\mathrm{x}$ Treat Years } & \multicolumn{3}{|c|}{$\begin{array}{c}\text { Pre-1999 Mahog Exp x Treat } \\
\text { Years }\end{array}$} & \multicolumn{3}{|c|}{$\begin{array}{c}\text { Mahog State x Pre-1999 Mahog } \\
\text { Exp x Treat Years }\end{array}$} \\
\hline & 1 & 2 & 3 & 4 & 5 & 6 & 7 & 8 & 9 \\
\hline \multirow[t]{2}{*}{ treat 1999} & 3.049 & & -0.253 & 10.52 & & -0.233 & 8.298 & & -1.278 \\
\hline & [3.039] & & [2.994] & [8.113] & & {$[2.896]$} & [6.574] & & [2.547] \\
\hline \multirow[t]{2}{*}{ treat 2002} & & 5.432 & 5.565 & & $21.78 * * *$ & $21.89 * * *$ & & $19.18^{* * *}$ & $19.80 * * *$ \\
\hline & & [3.298] & [3.562] & & {$[6.980]$} & {$[6.542]$} & & [5.593] & [5.389] \\
\hline controls included & $x$ & $x$ & $x$ & $x$ & $x$ & $x$ & $x$ & $x$ & $x$ \\
\hline Observations & 297 & 297 & 297 & 297 & 297 & 297 & 297 & 297 & 297 \\
\hline R-squared & 0.896 & 0.897 & 0.897 & 0.896 & 0.900 & 0.900 & 0.896 & 0.899 & 0.899 \\
\hline \multicolumn{10}{|c|}{$\begin{array}{l}\text { Obs.: Robust standard-errors in brackets (clustering at state); }{ }^{* * *} \mathrm{p}<0.01,{ }^{* *} \mathrm{p}<0.05,{ }^{*} \mathrm{p}<0.1 \text {. Dependent variable is the homicide rate (per } 100,000 \\
\text { inhabitants). All regressions include a constant, state and year dummies, and the following controls: gdp p.c. (In), \% of gdp in agric, state area planted, ratio of } \\
\text { top } 10 \% \text { to bottem } 40 \% \text { of income distrib, poverty rates, } \% \text { of household with more then } 2 \text { members per room, primary enrollment rate btwn } 7 \text { and } 14,55 \text { of } \\
\text { informality in labor force, } \% \text { pop with access to water, } \% \text { pop with access to sewage, } \% \text { labor force in agriculture, unemployment, illiteracy, electricity } \\
\text { consumption p.c. (In). Regressions are weighted by state population. } 27 \text { states. Treatment variables are dummies }=1 \text { after } 1999 \text { and } 2002 \text { interacted with } \\
\text { dummy of mahogany occurrence in state (1-3); state share in total pre-1999 mahogany exports (4-6); dummy of mahogany occurrence in state interacted with } \\
\text { state share in total pre- } 1999 \text { mahogany exports ( } 7-9) \text {. }\end{array}$} \\
\hline
\end{tabular}


Table 6: Illegality of Mahogany Trade and Homicides, Placebos, Brazilian States, 1995-2007, Difference-in-difference

\begin{tabular}{|c|c|c|c|}
\hline \multirow[t]{2}{*}{ Treatment: } & \multirow{2}{*}{$\begin{array}{c}\text { Mahog Area x Treat Years } \\
1\end{array}$} & \multirow{2}{*}{$\begin{array}{l}\text { Pre-1999 Mahog Exp x } \\
\text { Treat Years } \\
\\
2\end{array}$} & \multirow{2}{*}{$\begin{array}{c}\text { Mahog State x Pre-1999 } \\
\text { Mahog Exp x Treat Years } \\
3\end{array}$} \\
\hline & & & \\
\hline \multirow[t]{2}{*}{ treat 1999} & -0.361 & -2.107 & -2.492 \\
\hline & [2.704] & [3.463] & [2.991] \\
\hline \multirow[t]{2}{*}{ treat 2002} & 6.069 & $18.04 * *$ & $16.81 * *$ \\
\hline & [5.448] & [6.862] & [6.321] \\
\hline \multicolumn{4}{|c|}{ pre-intervention } \\
\hline \multirow[t]{2}{*}{ placebos } & 0.200 & -0.241 & -0.428 \\
\hline & [1.766] & [1.968] & [1.683] \\
\hline Observations & 351 & 351 & 351 \\
\hline R-squared & 0.831 & 0.833 & 0.832 \\
\hline \multicolumn{4}{|c|}{ 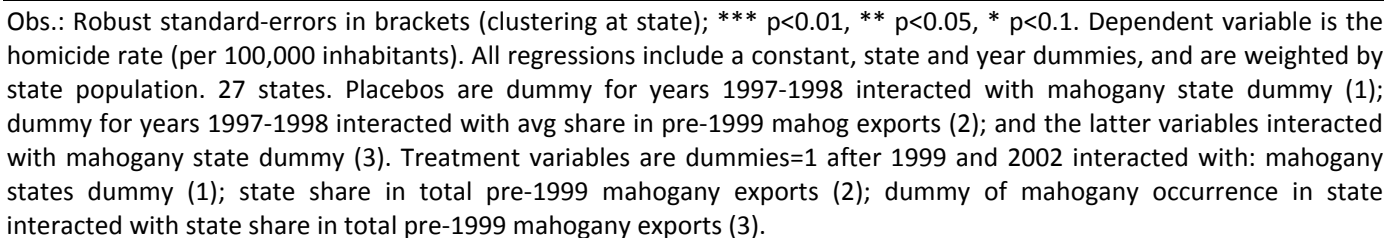 } \\
\hline
\end{tabular}


Table 7: Illegality of Mahogany Trade and Homicides, Robustness with Export of Other Woods after Prohibition, Brazilian States, 1995-2007, Difference-in-difference

\begin{tabular}{|c|c|c|c|c|c|c|c|c|}
\hline \multirow[t]{2}{*}{ Treatment: } & \multicolumn{3}{|c|}{$\begin{array}{c}\text { Other Wood Exp x Treat } \\
\text { Years }\end{array}$} & \multicolumn{3}{|c|}{$\begin{array}{c}\text { Mahog State } \times \text { Other Wood } \\
\text { Exp } \times \text { Treat Years }\end{array}$} & \multirow{2}{*}{$\begin{array}{c}\text { Other Wood Exp } \mathrm{x} \\
\text { Treat Years } \\
7 \\
\end{array}$} & \multirow{2}{*}{$\begin{array}{c}\text { Mahog State } \times \text { Other Wood } \\
\text { Exp } \times \text { Treat Years } \\
8 \\
\end{array}$} \\
\hline & 1 & 2 & 3 & 4 & 5 & 6 & & \\
\hline \multirow[t]{2}{*}{ treat 1999} & $0.0832^{* *}$ & & -0.0145 & $0.0800 * *$ & & -0.0159 & -0.0119 & -0.0126 \\
\hline & {$[0.0330]$} & & {$[0.0144]$} & {$[0.0304]$} & & {$[0.0141]$} & [0.0147] & [0.0144] \\
\hline \multirow[t]{2}{*}{ treat 2002} & & $0.0855^{* *}$ & * $0.0969 * *$ & & $0.0826^{* *}$ & ${ }^{*} 0.0951^{* *}$ & $0.0958^{* * *}$ & $0.0937^{* * *}$ \\
\hline & & [0.0327] & {$[0.0352]$} & & [0.0305] & {$[0.0344]$} & {$[0.0338]$} & [0.0329] \\
\hline \multirow[t]{2}{*}{ pre-interv. placebos } & & & & & & & 0.315 & 0.397 \\
\hline & & & & & & & {$[0.682]$} & {$[0.641]$} \\
\hline Observations & 351 & 351 & 351 & 351 & 351 & 351 & 351 & 351 \\
\hline R-squared & 0.832 & 0.834 & 0.834 & 0.832 & 0.834 & 0.834 & 0.834 & 0.834 \\
\hline \multirow[t]{2}{*}{ Treatment: } & \multicolumn{3}{|c|}{$\begin{array}{c}\text { Other Wood Exp x Treat } \\
\text { Years }\end{array}$} & \multicolumn{3}{|c|}{$\begin{array}{c}\text { Mahog State } \times \text { Other Wood } \\
\text { Exp } \times \text { Treat Years }\end{array}$} & & \\
\hline & 9 & 10 & 11 & 12 & 13 & 14 & & \\
\hline \multirow[t]{2}{*}{ treat 1999} & $0.124 * * *$ & & -0.00238 & $0.113^{* * *}$ & & -0.0106 & & \\
\hline & [0.0349] & & {$[0.0234]$} & [0.0296] & & [0.0199] & & \\
\hline \multirow[t]{2}{*}{ treat 2002} & & $0.123^{* * *}$ & $0.125^{* * *}$ & & $0.113^{* * *}$ & $0.122 * * *$ & & \\
\hline & & [0.0303] & {$[0.0301]$} & & {$[0.0270]$} & {$[0.0293]$} & & \\
\hline controls included & $x$ & $x$ & $x$ & $x$ & $x$ & $x$ & & \\
\hline Observations & 297 & 297 & 297 & 297 & 297 & 297 & & \\
\hline R-squared & 0.901 & 0.902 & 0.902 & 0.900 & 0.901 & 0.901 & & \\
\hline
\end{tabular}


Table 8: Illegality of Mahogany Trade and Homicides, Brazilian Municipalities, 1995-2007, Difference-in-difference

\begin{tabular}{|c|c|c|c|c|c|c|c|c|c|}
\hline \multirow[t]{2}{*}{ Treatment: } & \multicolumn{3}{|c|}{ Mahog Area x Treat Years } & \multicolumn{3}{|c|}{$\begin{array}{c}\text { Pre-1999 Mahog Exp x Treat } \\
\text { Years }\end{array}$} & \multicolumn{3}{|c|}{$\begin{array}{c}\text { Mahog Area x Pre-1999 Mahog } \\
\text { Exp x Treat Years }\end{array}$} \\
\hline & 1 & 2 & 3 & 4 & 5 & 6 & 7 & 8 & 9 \\
\hline \multirow[t]{2}{*}{ treat 1999} & $7.524^{* *}$ & & 2.711 & $10.29 * *$ & & -2.214 & $23.16 * * *$ & & 6.964 \\
\hline & [3.197] & & [2.164] & [3.894] & & [2.619] & [7.042] & & [4.591] \\
\hline \multirow[t]{2}{*}{ treat 2002} & & $8.478 * * *$ & $7.012 * *$ & & $16.98 * * *$ & $18.19 * *$ & & $27.29 * * *$ & $23.56 * * *$ \\
\hline & & [3.239] & {$[2.751]$} & & [6.102] & {$[6.765]$} & & [6.583] & [4.916] \\
\hline Observations & 65,804 & 65,804 & 65,804 & 65,804 & 65,804 & 65,804 & 65,804 & 65,804 & 65,804 \\
\hline R-squared & 0.730 & 0.730 & 0.730 & 0.730 & 0.732 & 0.732 & 0.730 & 0.731 & 0.731 \\
\hline
\end{tabular}


Table 9: Illegality of Mahogany Trade and Homicides, Controls Included, Brazilian Municipalities, 1995-2007, Difference-indifference

\begin{tabular}{|c|c|c|c|c|c|c|c|c|c|}
\hline \multirow[t]{2}{*}{ Treatment: } & \multicolumn{3}{|c|}{ Mahog Area x Treat Years } & \multicolumn{3}{|c|}{$\begin{array}{c}\text { Pre-1999 Mahog Exp x Treat } \\
\text { Years }\end{array}$} & \multicolumn{3}{|c|}{$\begin{array}{c}\text { Mahog Area x Pre-1999 Mahog } \\
\text { Exp x Treat Years }\end{array}$} \\
\hline & 1 & 2 & 3 & 4 & 5 & 6 & 7 & 8 & 9 \\
\hline \multirow[t]{2}{*}{ treat 1999} & $10.11 * * *$ & & $6.866^{*}$ & $12.37^{* * *}$ & & 4.230 & $23.10 * * *$ & & 8.285 \\
\hline & [3.121] & & [4.051] & [4.014] & & [3.173] & [5.921] & & [5.554] \\
\hline \multirow[t]{2}{*}{ treat 2002} & & $6.907 * * *$ & 4.931 & & $14.36 * * *$ & $13.18^{* * *}$ & & $22.58 * * *$ & $20.19 * * *$ \\
\hline & & [2.488] & [3.070] & & [2.013] & [1.659] & & [5.749] & [6.045] \\
\hline controls included & $x$ & $x$ & $x$ & $x$ & $x$ & $x$ & $x$ & $x$ & $x$ \\
\hline Observations & 45,218 & 45,218 & 45,218 & 45,218 & 45,218 & 45,218 & 45,218 & 45,218 & 45,218 \\
\hline R-squared & 0.797 & 0.797 & 0.797 & 0.797 & 0.798 & 0.798 & 0.797 & 0.797 & 0.797 \\
\hline
\end{tabular}


Table 10: Illegality of Mahogany Trade and Homicides, Sample Restricted to Mahogany Occuring States, Brazilian Municipalities, 1995-2007, Difference-indifference

\begin{tabular}{|c|c|c|c|c|c|c|c|c|c|c|c|c|}
\hline \multirow[t]{2}{*}{ Treatment: } & \multicolumn{6}{|c|}{ Mahog Area x Treat Years } & \multicolumn{6}{|c|}{ Mahog Area x Pre-1999 Mahog Exp x Treat Years } \\
\hline & 1 & 2 & 3 & 4 & 5 & 6 & 7 & 8 & 9 & 10 & 11 & 12 \\
\hline \multirow[t]{2}{*}{ treat 1999} & $5.327^{* *}$ & & $3.959 *$ & $5.187^{*}$ & & 2.098 & $19.92 * * *$ & & $8.338^{*}$ & $15.21 * * *$ & & 3.018 \\
\hline & {$[2.608]$} & & {$[2.186]$} & {$[2.858]$} & & {$[2.902]$} & {$[6.452]$} & & [4.569] & {$[5.650]$} & & {$[4.288]$} \\
\hline \multirow[t]{2}{*}{ treat 2002} & & 4.139 & 1.993 & & $5.659 * *$ & $5.118 * *$ & & $21.31^{* * *}$ & $16.84 * * *$ & & $17.95^{* * *}$ & $17.10 * * *$ \\
\hline & & [2.588] & [2.428] & & [2.436] & [2.524] & & [5.865] & [4.418] & & [4.783] & [4.483] \\
\hline controls included & & & & $x$ & $x$ & $x$ & & & & $x$ & $x$ & $x$ \\
\hline Observations & 9,045 & 9,045 & 9,045 & 6,260 & 6,260 & 6,260 & 9,045 & 9,045 & 9,045 & 6,260 & 6,260 & 6,260 \\
\hline R-squared & 0.690 & 0.690 & 0.691 & 0.753 & 0.755 & 0.755 & 0.695 & 0.699 & 0.700 & 0.754 & 0.759 & 0.759 \\
\hline
\end{tabular}


Table 11: Illegality of Mahogany Trade and Homicides, Sample Restricted to State of Pará, Brazilian Municipalities, 1995-2007, Difference-in-difference

\begin{tabular}{|c|c|c|c|c|c|c|}
\hline \multirow[t]{2}{*}{ Treatment: } & \multicolumn{6}{|c|}{ Mahog Area x Treat Years } \\
\hline & 1 & 2 & 3 & 4 & 5 & 6 \\
\hline \multirow[t]{2}{*}{ treat 1999} & $13.45^{* * *}$ & & $9.074 * *$ & $10.88 * * *$ & & 5.649 \\
\hline & [4.753] & & [3.504] & [3.980] & & [3.701] \\
\hline \multirow[t]{2}{*}{ treat 2002} & & $11.24^{* *}$ & $6.359 *$ & & $9.414 * * *$ & $8.149 * * *$ \\
\hline & & [4.369] & [3.432] & & [3.087] & [3.093] \\
\hline controls included & & & & $x$ & $x$ & $x$ \\
\hline Observations & 1,748 & 1,748 & 1,748 & 1,321 & 1,321 & 1,321 \\
\hline R-squared & 0.717 & 0.716 & 0.720 & 0.787 & 0.792 & 0.793 \\
\hline \multicolumn{7}{|c|}{$\begin{array}{l}\text { Obs.: Robust standard-errors in brackets (clustering at municipality for columns } 1-3 \text { and } 7-9 \text {, and at state for columns } 4-6 \text { ); }{ }^{* * *} \\
\text { p<0.01, }{ }^{* *} p<0.05,{ }^{*} p<0.1 \text {. Dependent variable is the homicide rate (per } 100,000 \text { inhabitants). All regressions include a } \\
\text { constant, state and year dummies, and are weighted by state population. Municipality level controls include: gdp p.c. (In), \% o } \\
\text { gdp in agric, and municipality area planted. State level time varying controls include: ratio of top } 10 \% \text { to bottem } 40 \% \text { of income } \\
\text { distrib, poverty rates, \% of household with more then } 2 \text { members per room, primary enrollment rate btwn } 7 \text { and } 14,55 \text { o } \\
\text { informality in labor force, \% pop with access to water, \% pop with access to sewage, \% labor force in agriculture } \\
\text { unemployment, illiteracy, electricity consumption p.c. (In). Treatment variables are dummies }=1 \text { after } 1999 \text { and } 2002 \text { interactec } \\
\text { with dummy of mahogany occurring area. }\end{array}$} \\
\hline
\end{tabular}


Table 12: Illegality of Mahogany Trade and Homicides, Placebos, Brazilian Municipalities, 1995-2007, Difference-in-difference

\begin{tabular}{|c|c|c|c|c|c|c|}
\hline Treatment: & $\begin{array}{c}\text { Mahog Area x Treat } \\
\text { Years }\end{array}$ & $\begin{array}{l}\text { Pre-1999 Mahog Exp x } \\
\text { Treat Years }\end{array}$ & $\begin{array}{l}\text { Mahog Area x Pre- } \\
1999 \text { Mahog Exp x } \\
\text { Treat Years }\end{array}$ & $\begin{array}{c}\text { Mahog Area x Treat } \\
\text { Years }\end{array}$ & $\begin{array}{l}\text { Mahog Area x Pre- } \\
1999 \text { Mahog Exp x } \\
\text { Treat Years }\end{array}$ & $\begin{array}{c}\text { Mahog Area x Treat } \\
\text { Years }\end{array}$ \\
\hline \multirow[t]{2}{*}{ Sample: } & \multicolumn{3}{|c|}{ All States } & \multicolumn{2}{|c|}{ Only Mahogany Occurring States } & Only Pará \\
\hline & 1 & 2 & 3 & 4 & 5 & 6 \\
\hline \multirow[t]{2}{*}{ treat 1999} & 3.713 & -2.531 & $6.641^{* *}$ & $5.104^{*}$ & 7.780 & $8.785^{* *}$ \\
\hline & [3.451] & [3.441] & [3.160] & [3.071] & [4.764] & [3.812] \\
\hline \multirow[t]{2}{*}{ treat 2002} & $7.013^{* *}$ & $18.19^{* *}$ & $23.56 * * *$ & 1.994 & $16.84^{* * *}$ & $6.359 *$ \\
\hline & [2.751] & [6.764] & [6.465] & [2.427] & [4.418] & [3.433] \\
\hline \multicolumn{7}{|c|}{ pre-intervention } \\
\hline \multirow[t]{2}{*}{ placebos } & 1.935 & -0.615 & -0.609 & 2.213 & -1.054 & -0.551 \\
\hline & [3.232] & [1.927] & [2.071] & [2.483] & [2.530] & [2.287] \\
\hline Observations & 65,804 & 65,804 & 65,804 & 9,045 & 9,045 & 1,748 \\
\hline R-squared & 0.730 & 0.732 & 0.731 & 0.691 & 0.700 & 0.720 \\
\hline
\end{tabular}


Figure 1: Exports of Mahogany and Other Tropical Timber Species (in Kgs), Brazil, 1989-2009

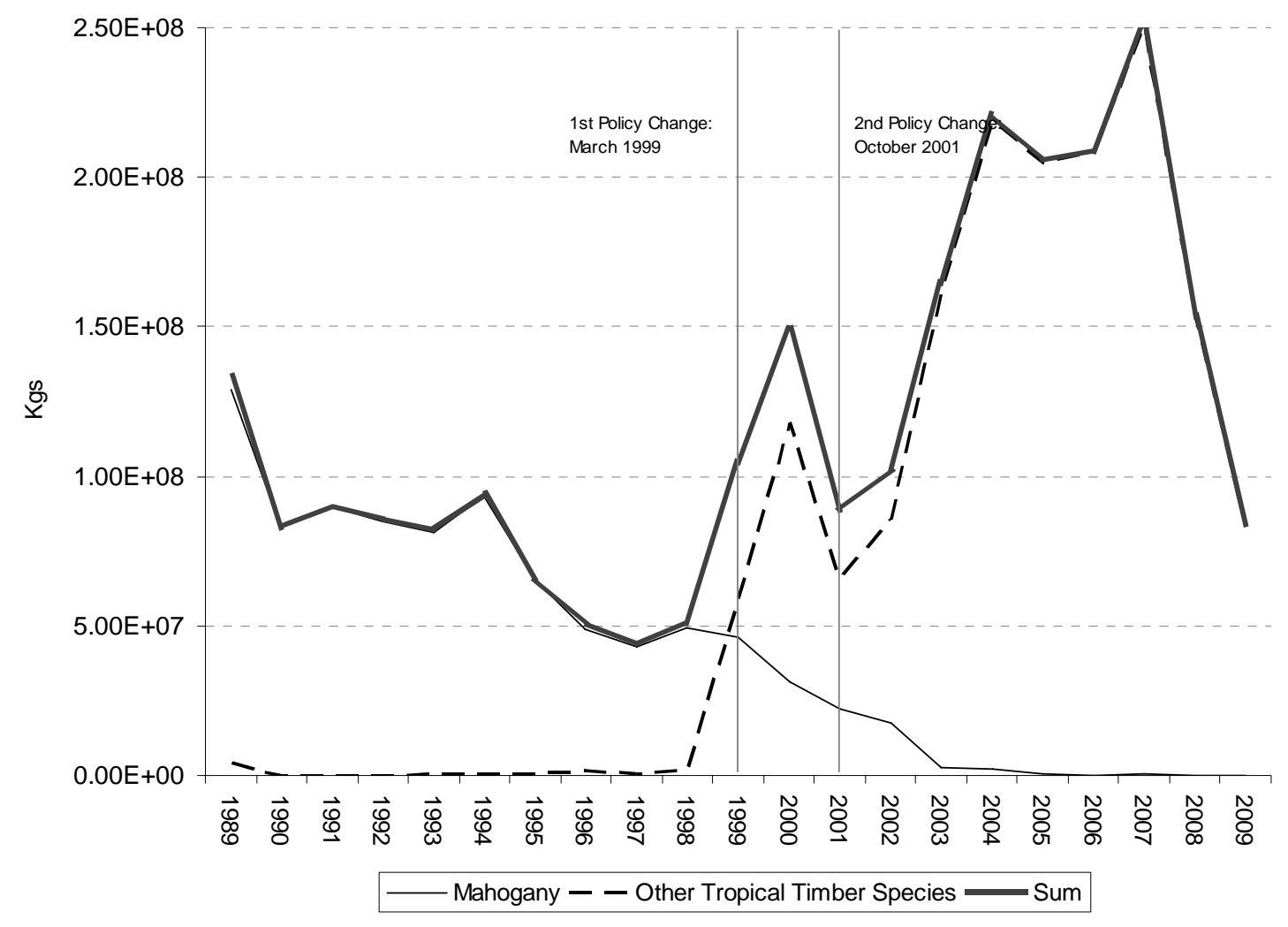


Figure 2: Evolution of Homicide Rates (per 100,000) in Brazil, Various Areas, 1995-2007

(a) Brazilian States, 1995-2007

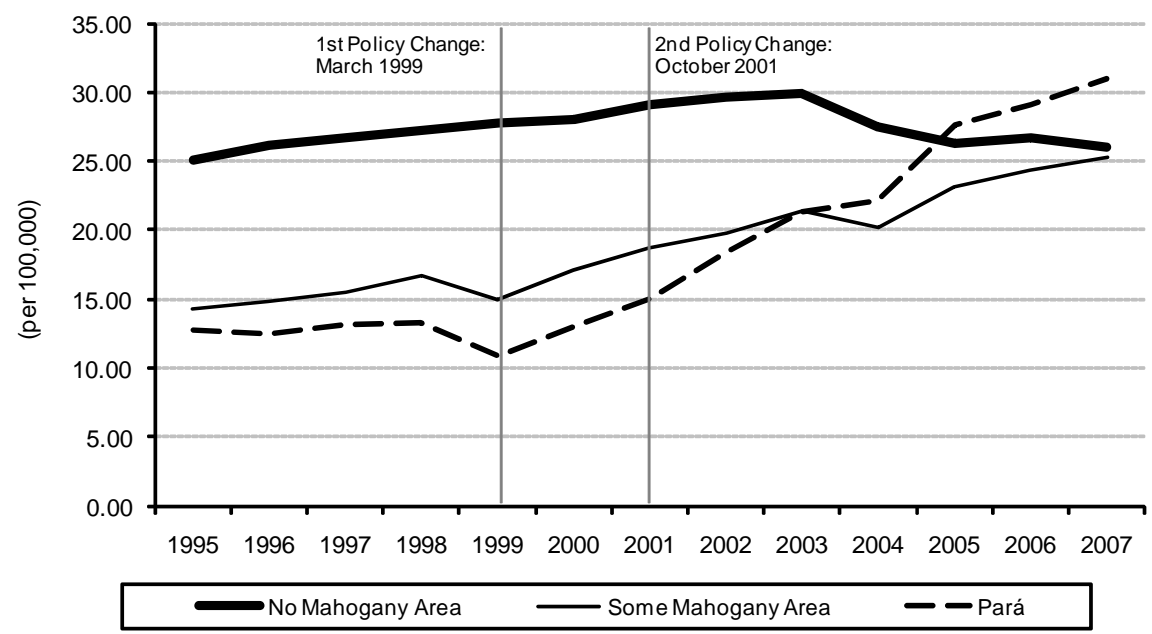

(b) Brazilian Municipalities, 1995-2007

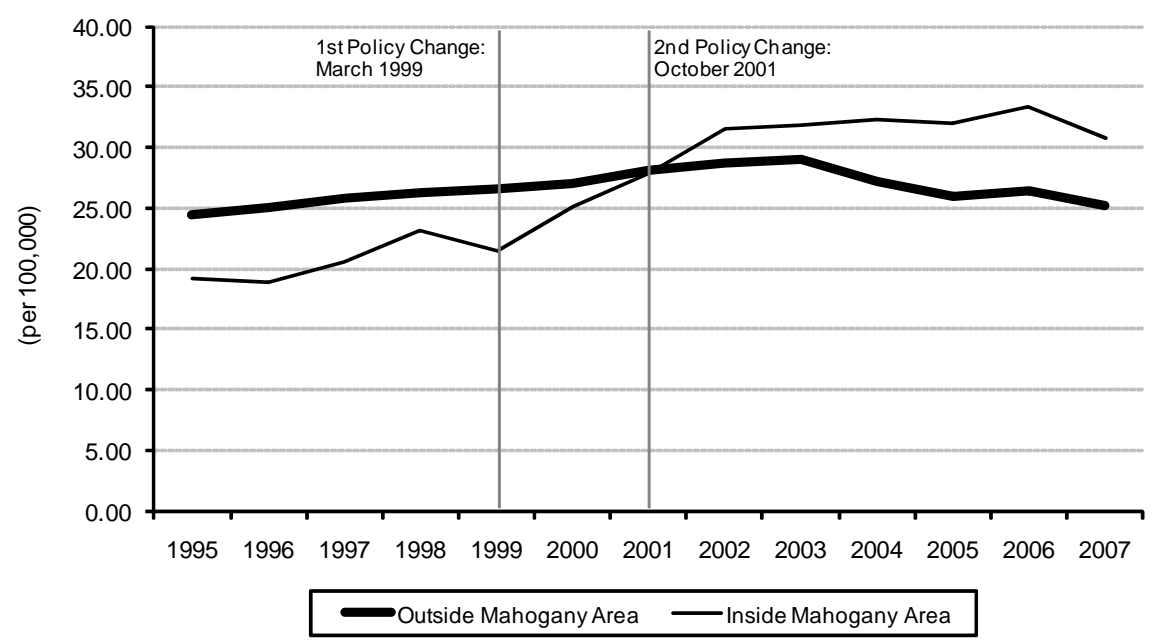

(c) Municipalities in the Brazilian State of Pará, 1995-2007

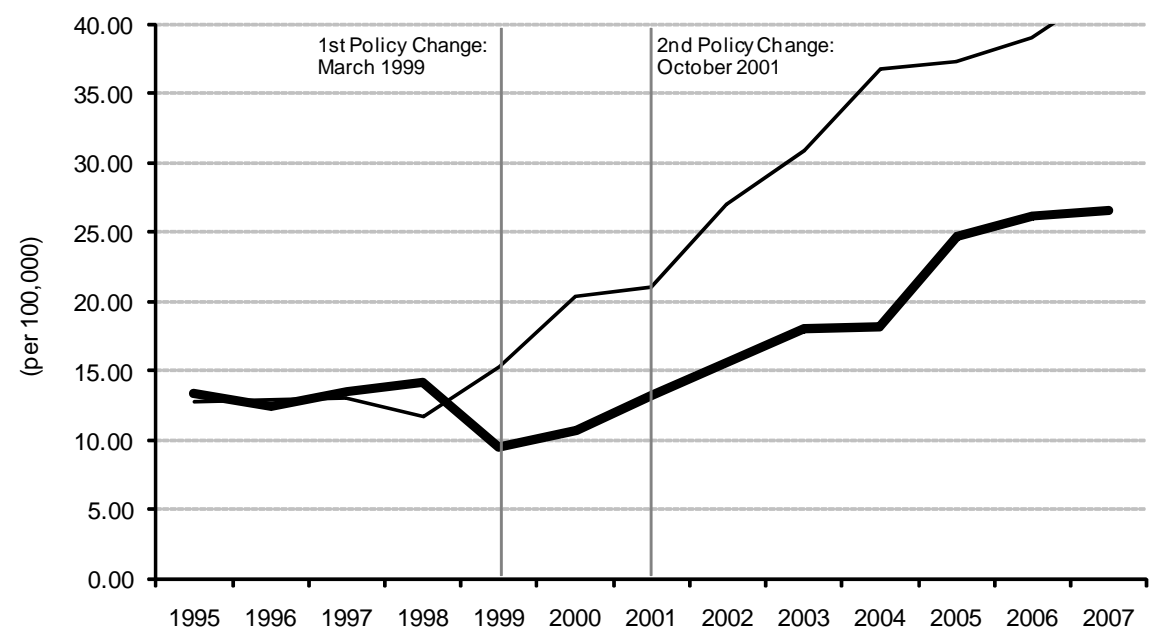

Outside Mahogany Area

- Inside Mahogany Area 
Figure 3a: Exports of "Other Tropical Timber Species" from the States of Amazonas, Pará, Mato Grosso, and Rondônia, Brazil, 1989-2010 - Monthly Data

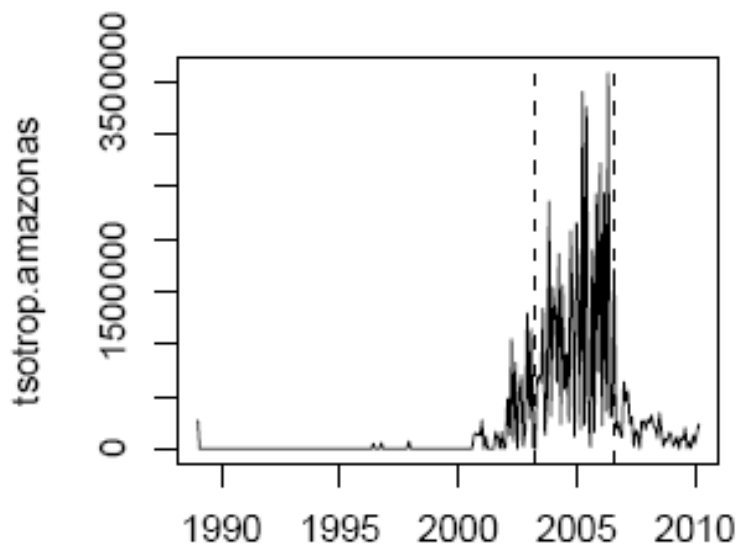

Time

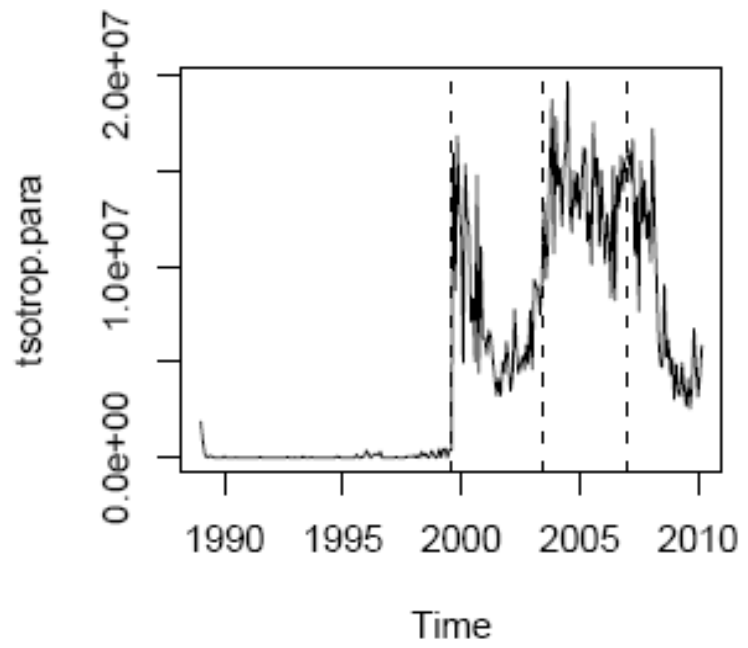

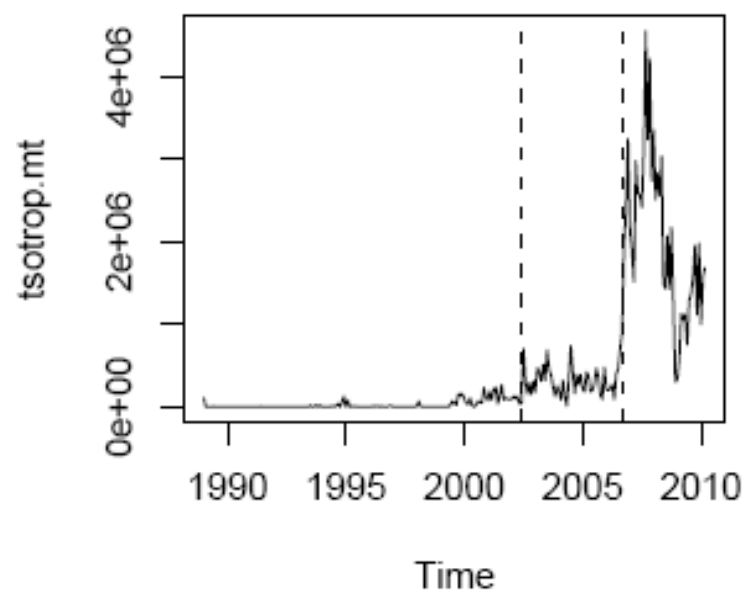

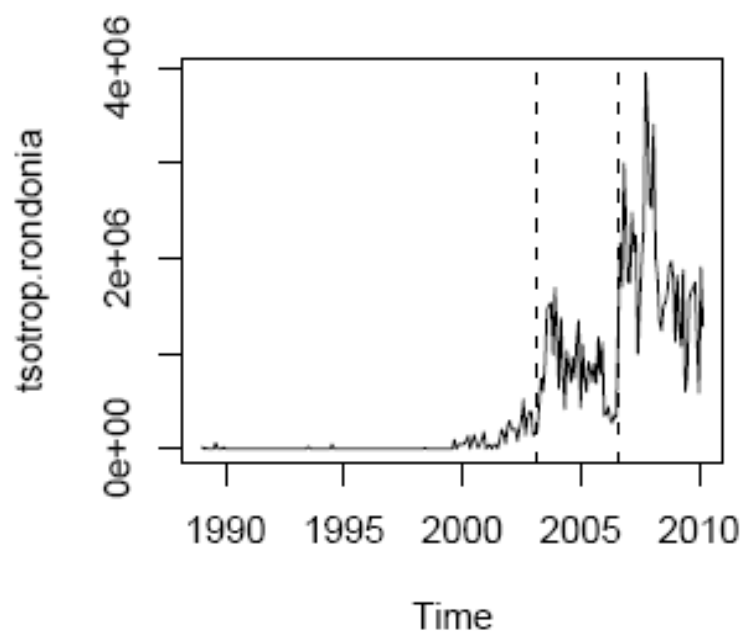


Figure 3b: Exports of "Other Tropical Timber Species" from the States of Amazonas, Pará, Mato Grosso, and Rondônia, Brazil, 1989-2010 - Annual Data
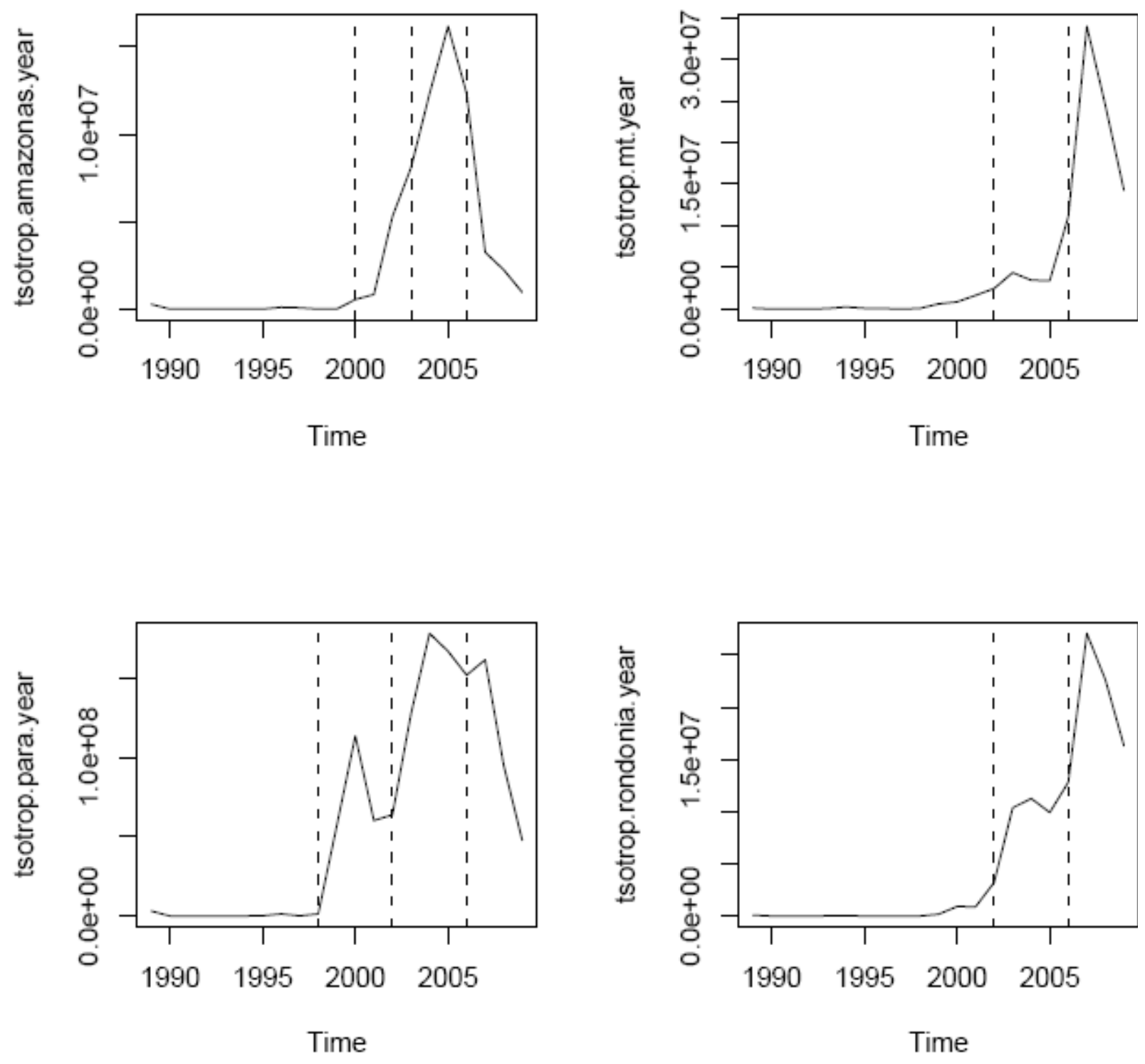